\title{
Scaling Gross Primary Production (GPP) over boreal and deciduous forest landscapes in support of MODIS GPP product validation
}

\author{
David P. Turner ${ }^{\mathrm{a}, *}$, William D. Ritts ${ }^{\mathrm{a}}$, Warren B. Cohen ${ }^{\mathrm{b}}$, Stith T. Gower ${ }^{\mathrm{c}}$, Maosheng Zhao ${ }^{\mathrm{d}}$, \\ Steve W. Running ${ }^{\mathrm{d}}$, Steven C. Wofsy ${ }^{\mathrm{e}}$, Shawn Urbanski ${ }^{\mathrm{e}}$, Allison L. Dunn ${ }^{\mathrm{e}}$, J.W. Munger ${ }^{\mathrm{e}}$

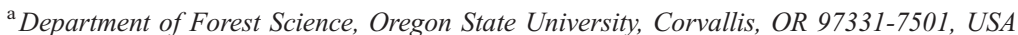 \\ ${ }^{\mathrm{b}}$ USDA Forest Service, 3200 SW Jefferson Way, Corvallis, OR 97331, USA \\ ${ }^{\mathrm{c}}$ Department of Forest Ecology and Management, University of Wisconsin, Madison, WN 53706, USA \\ ${ }^{\mathrm{d}}$ School of Forestry, University of Montana, Missoula, MT 59812, USA \\ ${ }^{\mathrm{e}}$ Department of Earth and Planetary Sciences, Harvard University Cambridge, MA 02138, USA
}

Received 10 February 2003; received in revised form 16 June 2003; accepted 18 June 2003

\begin{abstract}
The Moderate Resolution Imaging Radiometer (MODIS) is the primary instrument in the NASA Earth Observing System for monitoring the seasonality of global terrestrial vegetation. Estimates of 8-day mean daily gross primary production (GPP) at the $1 \mathrm{~km}$ spatial resolution are now operationally produced by the MODIS Land Science Team for the global terrestrial surface using a production efficiency approach. In this study, the 2001 MODIS GPP product was compared with scaled GPP estimates $\left(25 \mathrm{~km}^{2}\right)$ based on ground measurements at two forested sites. The ground-based GPP scaling approach relied on a carbon cycle process model run in a spatially distributed mode. Land cover classification and maximum annual leaf area index, as derived from Landsat ETM+ imagery, were used in model initiation. The model was driven by daily meteorological observations from an eddy covariance flux tower situated at the center of each site. Model simulated GPPs were corroborated with daily GPP estimates from the flux tower. At the hardwood forest site, the MODIS GPP phenology started earlier than was indicated by the scaled GPP, and the summertime GPP from MODIS was generally lower than the scaled GPP values. The fall-off in production at the end of the growing season was similar to the validation data. At the boreal forest site, the GPP phenologies generally agreed because both responded to the strong signal associated with minimum temperature. The midsummer MODIS GPP there was generally higher than the ground-based GPP. The differences between the MODIS GPP products and the ground-based GPPs were driven by differences in the timing of FPAR and the magnitude of light use efficiency as well as by differences in other inputs to the MODIS GPP algorithm-daily incident PAR, minimum temperature, and vapor pressure deficit. Ground-based scaling of GPP has the potential to improve the parameterization of light use efficiency in satellite-based GPP monitoring algorithms.
\end{abstract}

(C) 2003 Elsevier Inc. All rights reserved.

Keywords: MODIS; Validation; Gross primary production; Light use efficiency; Eddy covariance; Biome-BGC; FPAR; Boreal forest; Deciduous forest

\section{Introduction}

Anthropogenic influences on the global carbon cycle include direct $\mathrm{CO}_{2}$ emissions to the atmosphere associated with combustion of fossil fuel, as well as indirect effects mediated by the biospheric cycling of carbon (Schimel, 1995). Notably, human-induced land cover change and land use change produce large sources and sinks of carbon (Houghton, 1999). Furthermore, increasing atmospheric

* Corresponding author. Tel.: +1-541-737-5043; fax: +1-541-7371393.

E-mail address: david.turner@oregonstate.edu (D.P. Turner). concentrations of $\mathrm{CO}_{2}$ and pollutants such as ozone, along with atmospheric deposition of nitrogen and sulfur, are altering carbon uptake by gross primary production and carbon release by autotrophic and heterotrophic respiration. Interannual variation in regional (e.g. Nemani et al., 2002) and global climate, and a global trend towards climate warming - most likely driven by the rising concentrations of greenhouse gases (IPCC, 2001) - are also strongly modifying the carbon cycle. To understand the relative magnitude of these various factors, it will be important to monitor critical components of the biospheric carbon cycle at regional and global scales (Running et al., 1999).

The Moderate Imaging Spectroradiometer (MODIS) sensor was designed in part for that purpose and global 
estimates of 8-day gross primary production (GPP) and annual net primary production (NPP) at the $1 \mathrm{~km}$ spatial resolution are now being produced operationally (Running, Thornton, Nemani, \& Glassy, 2000). Both GPP and NPP estimates require validation with ground-based measurements. NPP is perhaps more directly relevant to carbon cycle analysis but validating only NPP is undesirable because the MODIS NPP product is calculated as the difference between GPP and autotrophic respiration $\left(R_{a}\right)$. The MODIS GPP and $\mathrm{R}_{\mathrm{a}}$ algorithms both rely upon remote sensing but in very different ways and each algorithm needs to be investigated. In this study, an initial evaluation of the MODIS 2001 GPP product is made by comparing MODIS GPP estimates with ground-based GPP estimates over 25 $\mathrm{km}^{2}$ areas at a northern hardwoods forest site and a boreal forest site.

The MODIS GPP algorithm employs a light use efficiency approach (Running et al., 2000). GPP is estimated for each $1 \mathrm{~km}^{2}$ cell for each day of the year by first determining the absorbed photosynthetically active radiation (APAR). The incident PAR and the fraction of PAR that is absorbed by the vegetation (FPAR) determine APAR. Their product is multiplied by a GPP light use efficiency $\left(\varepsilon_{\mathrm{g}}\right)$, in terms of $\mathrm{g} \mathrm{C} \mathrm{MJ}^{-1}$, to get daily GPP. FPAR for each $1 \mathrm{~km}$ cell is based on the spectral reflectances detected by the MODIS sensor (Myneni et al., 2002). The daily $\varepsilon_{\mathrm{g}}$ is based on a biome-specific maximum $\left(\varepsilon_{\mathrm{gmax}}\right)$ derived from a lookup table and modified by scalars $(0-1)$ associated with a daily minimum air temperature and vapor pressure deficit (VPD). PAR, temperature and VPD are from a data assimilation General Circulation Model (Schubert et al., 1993) run at the $1^{\circ}$ spatial resolution $(\sim 100 \mathrm{~km})$. The multiple inputs to the MODIS GPP algorithm are each subject to uncertainty and require evaluation in validation efforts.

Prospects for validating the MODIS GPP product are constrained by uncertainties in the measurement of GPP. GPP is the net effect of gross photosynthesis and photorespiration, and is not directly measurable. At the annual time step, GPP minus autotrophic respiration $\left(\mathrm{R}_{\mathrm{a}}\right)$ is equal to NPP, which is directly measurable (Gower, Kucharik, \& Norman, 1999). However, the ratio of NPP to GPP is not constant across plant functional types (Amthor, 2000) and scaling $\mathrm{R}_{\mathrm{a}}$ from air temperature and chamber measurements (e.g. Law, Ryan, \& Anthoni, 1999) is a complex undertaking. Eddy covariance flux towers measure GPP indirectly as the difference between net ecosystem exchange (NEE) and ecosystem respiration $\left(\mathrm{R}_{\mathrm{e}}\right)$ during daylight periods (Goulden, Munger, Fan, Daube, \& Wofsy, 1996a; Turner et al., 2003). For these estimates, $R_{e}$ is either scaled from chamber measurements of soil and plant respiration (Ham \& Knapp, 1998) or from the relationship of air temperature to NEE during nighttime periods above a threshold friction velocity (Goulden et al., 1997). An increasing number of flux tower sites are producing GPP estimates with relevance to validating MODIS products (Falge et al., 2002; Turner et al., 2003).
There are also issues with mismatches in scale when trying to juxtapose tower-based GPPs with MODIS GPPs. The MODIS GPP product is at a $1-\mathrm{km}$ spatial resolution. The tower-based estimates of GPP represent a flux integrated over the tower "footprint", the size and shape of which depends on wind speed, wind direction, surface roughness, and atmospheric stability (Schmid, 2002). Thus, the footprint is not a fixed area and the tower is sampling a relatively small area compared to MODIS products over a given region.

An alternative approach to generating GPP data layers for validation purposes is employed in this study and relies on a spatially distributed carbon cycle process model as the principal scaling tool. Inputs of land cover and leaf area index (LAI) are based on high spatial resolution remote sensing (Landsat ETM+), and the model is driven by daily meteorological station data. Model parameterization, calibration, and validation are based on ground measurements of NPP and GPP. Because the model is run at fine spatial resolution over a gridded surface and outputs are at the daily time step, results can be spatially and temporally aggregated to match precisely the spatial and temporal scale of the MODIS products. The process-based nature of the scaling approach also permits investigation of possible mechanisms underlying differences between the MODIS GPPs and ground-based measurements.

\section{Methods}

\subsection{Overview}

The MODIS Land Science Team GPP product for 2001 was evaluated at two sites, a northern hardwoods forest in the Northeastern United States and a boreal forest site in Northern Manitoba, Canada. The two sites in this study (Table 1) are part of a network of nine sites (BigFoot, 2003) at which a standard protocol is being applied for validation of MODIS land cover, LAI, GPP, and NPP products (Cohen, Maiersperger, Gower, Turner, \& Running, 2003; Reich, Turner, \& Bolstad, 1999). The general approach was to calibrate and validate a daily time step carbon cycle process model with field measurements, and run the model cell by cell over a $25-\mathrm{m}$ grid covering an area of $25 \mathrm{~km}^{2}$. Model outputs of daily GPP at the $25 \mathrm{~m}$ resolution (the BigFoot product) were then aggregated spatially and temporally to permit direct comparisons with the MODIS products that are produced at a $1-\mathrm{km}$ spatial resolution

Table 1

Site location and long term average climate variables

\begin{tabular}{lllc}
\hline Site & Location & $\begin{array}{l}\text { Precipitation } \\
(\mathrm{cm})\end{array}$ & $\begin{array}{l}\text { Mean annual } \\
\text { temperature }\left({ }^{\circ} \mathrm{C}\right)\end{array}$ \\
\hline $\begin{array}{l}\text { Hardwood } \\
\text { Forest }\end{array}$ & lat: 42.53572 & 112 & 8.06 \\
Boreal & lon: -72.171997 & & -1.97 \\
Forest & lat: 55.88007 & 31 & \\
\hline
\end{tabular}


and an 8-day average temporal resolution (Running et al., 2000). Model inputs included land cover type and LAI as well as daily meteorological data.

\subsection{Sites}

The sites are $5 \times 5 \mathrm{~km}$, an area large enough to include multiple MODIS $1 \mathrm{~km}$ cells and minimize issues of geolocation and representativeness. Each site is approximately centered on an eddy covariance flux tower that makes continuous measurements of temperature, precipitation, solar radiation, humidity and NEE of carbon (Goulden et al., 1996a). Within the $25 \mathrm{~km}^{2}, 100$ plots are established that sample most intensively around the flux tower and more randomly over the remainder of the area. Measurements of LAI are made at all 100 plots and measurement of ANPP at 50 of the plots (Campbell, Burrows, Gower, \& Cohen, 1999).

The northern hardwoods forest site (HARV) is at Harvard Forest, a component of the Long Term Ecological Research (LTER) network. Vegetation in the $25 \mathrm{~km}^{2}$ area is predominantly deciduous broadleaf forest, with some evergreen needleleaf cover intermixed. Besides forests, the land cover includes features such as small urban areas, a golf course, and wetlands. Soils in the area developed on glacial till and significant areas of poorly drained swampland and marshland are present. The climate is temperate, with warm humid summers.

The Harvard Forest eddy covariance flux tower is one of the longest running tower sites in the world, having begun nearly continuous operation in late 1991. Details of the micrometeorological and flux measurements are available in

\section{a) Hardwood Forest Site}

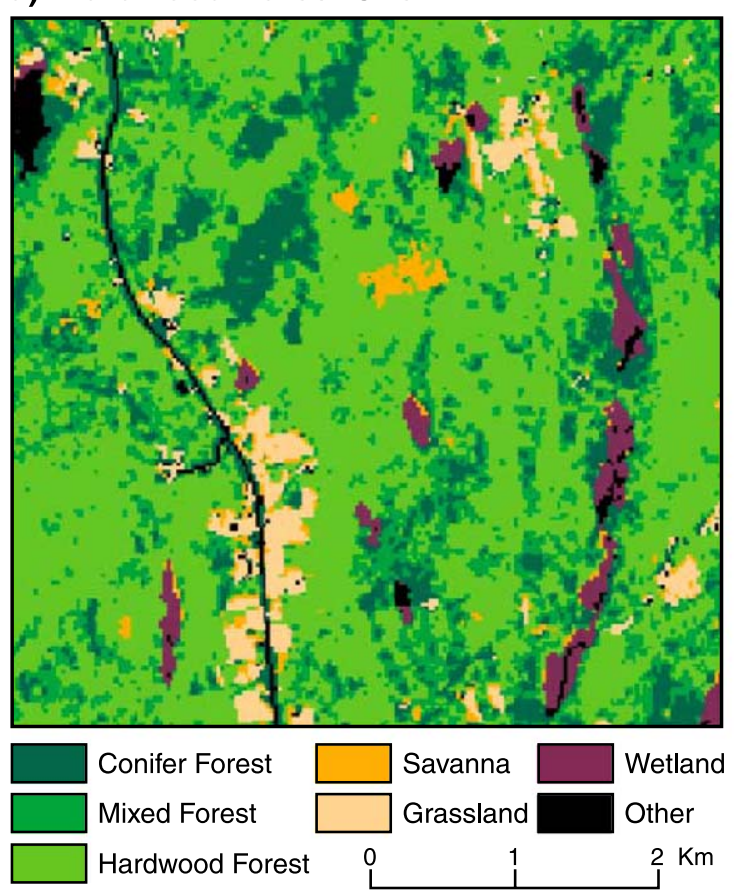

various publications (Barford et al., 2001; Goulden, Munger, Fan, Daube, \& Wofsy, 1996b; Wofsy et al., 1993) and the associated micrometeorological and mass flux data used in this study are available on the Internet (AmeriFlux, 2003).

The boreal forest site (NOBS for Northern Old Black Spruce) was one of six intensive research sites associated with the Northern Study Area of the BOREAS project (Sellers, Hall et al., 1997). Nearly continuous meteorological observations and eddy covariance measurements of NEE have been made at the NOBS site since 1994 (Goulden et al., 1997, 1998). Vegetation in the vicinity of the tower is predominately black spruce (Picea mariana), with areas of aspen (Populous tremuloides), jack pine (Pinus banksias), and wetlands also present. Vegetation cover is generally indicative of soil characteristics, with areas of jack pine and aspen in well-drained areas, upland black spruce (black spruce/feathermoss [Pleurozium schreberi]) in moderately drained areas, and open black spruce (black spruce/sphagnum [Spagnum sp.]) in poorly drained areas. Deep peat accumulation is associated with wetlands (Harden, O'Neill, Trumbore, Veldhuis, \& Stocks, 1997; Trumbore \& Harden, 1997). Climatically, the site is characterized by a short ( $\approx 140$ day), vigorous, growing season and moderate year round precipitation (Shewchuk, 1997).

\subsection{Land cover and leaf area index}

The land cover and seasonal maximum LAI data layers for model initialization were based on the BigFoot field

\section{b) Boreal Forest Site}

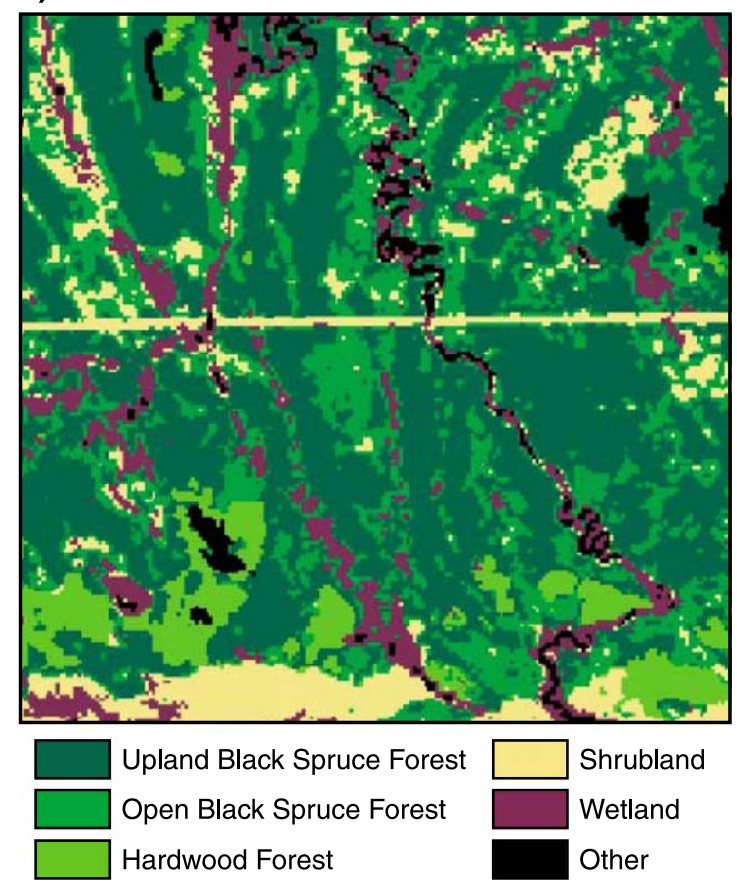

Fig. 1. Land cover at the study sites: (a) Hardwood Forest site, (b) Boreal Forest site. 
measurements (Campbell et al., 1999; Gower et al., 1999) and imagery from the Landsat ETM+ sensor collected during 2001 (Cohen et al., 2003). Land cover was mapped using a variety of methods and mid growing season LAI was mapped with empirical fits of the LAI observations to spectral reflectances at the plot locations (Cohen et al., 2003). The land cover classes in Cohen et al. (2003) were aggregated in some cases to simplify model parameterization (Fig. 1).

\subsection{Meteorological data}

The carbon cycle process model used for scaling GPP required daily values for minimum and maximum temper-

\section{a) Hardwood Forest Site}
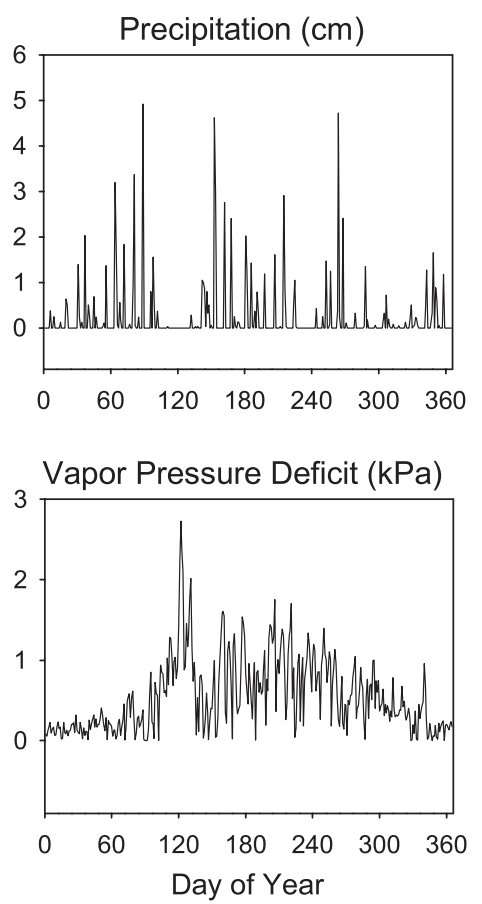

\section{b) Boreal Forest Site}
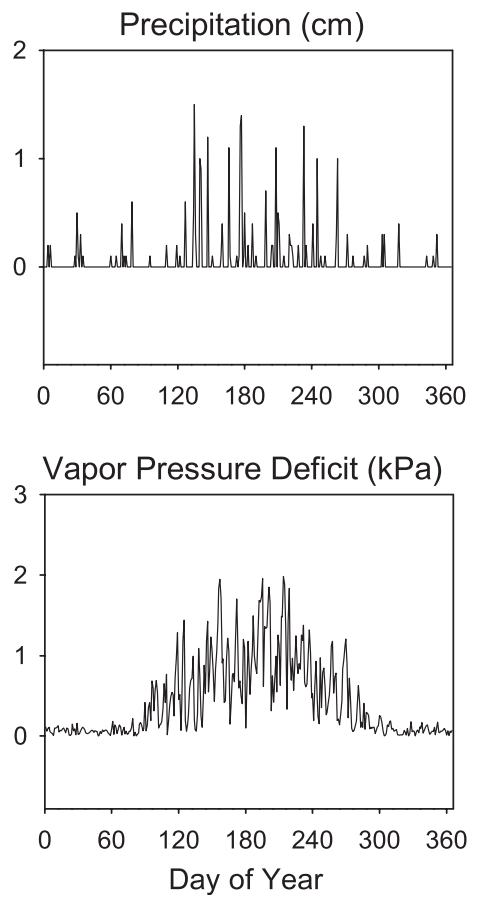
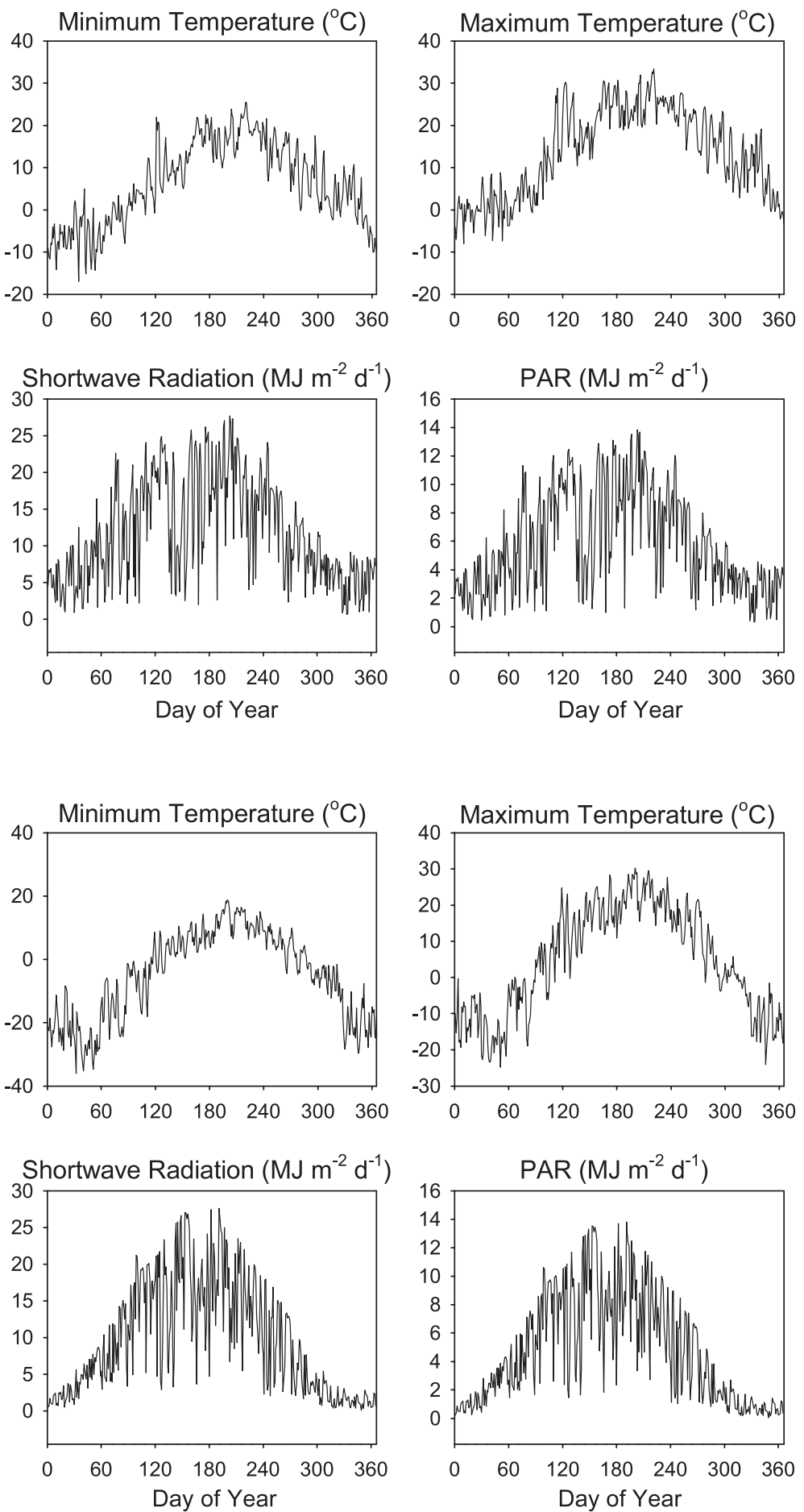

Fig. 2. Meteorological data used in model simulations: (a) Hardwood Forest site, (b) Boreal Forest site. 
ature, precipitation, solar radiation, photosynthetically active radiation, and vapor pressure deficit. For this study, half hourly observations from the flux towers (AmeriFlux, 2003) were aggregated to the daily time step (Fig. 2). Gaps in the data associated with instrument failure were filled with measurements at nearby meteorological stations. At HARV, there is significant topographic relief $(\sim 200 \mathrm{~m})$ and the daily values were interpolated to the $25 \mathrm{~m}$ cells to account for slope and aspect using the MTCLM (v4.3) model (Running, Nemani, \& Hungerford, 1987). After the interpolation, total annual PAR varied from 2000 to 2300 MJ m ${ }^{-2}$ year $^{-1}$ (Fig. 3). The daily time step meteorological data used in this study are available on the Internet (ORNL, 2003).

\subsection{Process model application}

The process model employed for scaling GPP was the Biome-BGC model (Kimball, Keyser, Running, \& Saatchi, 2000; Kimball, Running, \& Saatchi, 1999; Kimball, Thornton, White, \& Running, 1997; Running, 1994; Running \& Hunt, 1993). A version similar to that used in this study has been applied and tested in temperate (Coops, Waring, Brown, \& Running, 2001; Running, 1994) and boreal (Kimball et al., 1997, 1999) forests. The most recent published version of Biome-BGC (Thornton et al., 2002) was not used because it does not operate in a prescribed LAI mode, as was required for this application. Thus there is no model "spin-up" and no separation into sunlit and shade lit foliage. The model uses

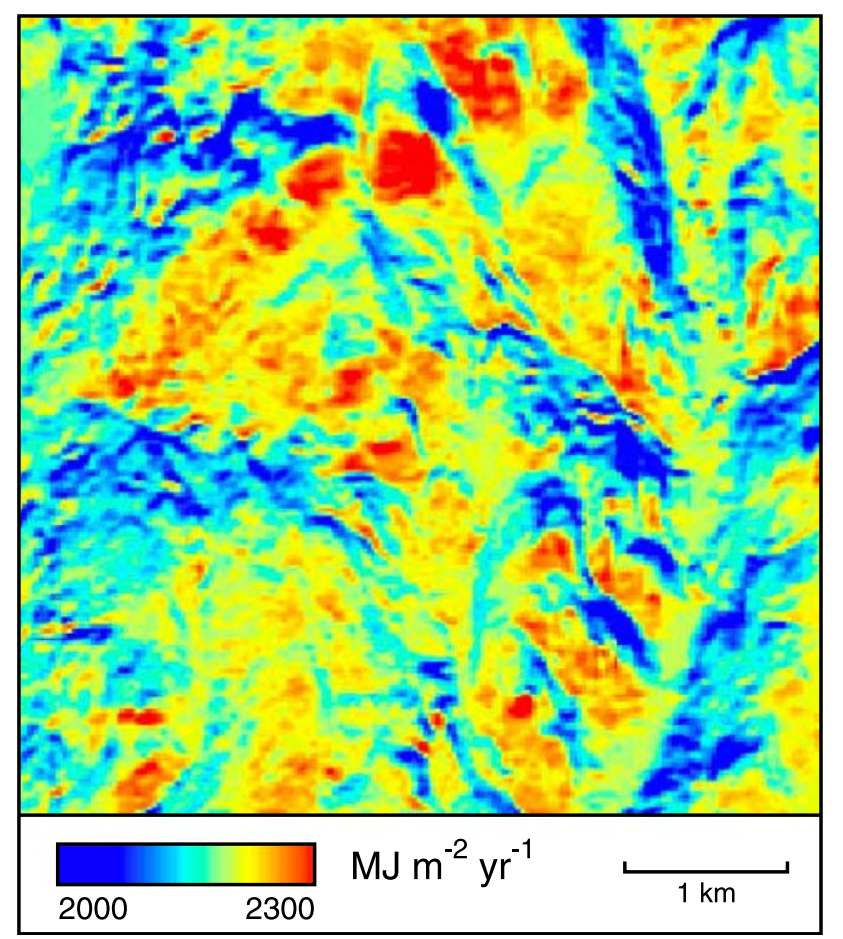

Fig. 3. Spatial distribution of the 2001 annual solar radiation at the Hardwood Forest site. a daily time step and simulates processes including photosynthesis and plant respiration. The autotrophic respiration algorithm in this version uses biomass nitrogen content and temperature (as in Thornton et al., 2002). The algorithm for net photosynthesis is based on the Farquhar biochemical model, and GPP is calculated as the sum of net photosynthesis and daytime foliar respiration. Biomass components include the foliage, live stem, live coarse roots, and fine roots.

Because of the potential importance of understory and ground cover vegetation layers in some cover types, the model was modified for this study to accommodate two vegetation layers within a cover type. Notably, the ground cover (including bryophytes) in black spruce dominated cover types, can contribute up to $40 \%$ of NPP yet its ecophysiological characteristics are quite different than those of the canopy (Bisbee, Gower, \& Norman, in press). PAR available for photosynthesis by the lower layer was PAR transmitted through the canopy, which in Biome-BGC is based on a simple Beer's Law radiation transfer formulation (Jarvis \& Leverenz, 1983).

Parameterization of the ecophysiological and allometric variables for each cover type, or vegetation layer within a cover type, was based on the literature review of White, Thornton, Running, and Nemani (2000) and on earlier applications of Biome-BGC and similar process models in these biomes (Frolking et al., 1996; Kimball et al., 1999, 1997; Running, 1994). Biomass carbon pools were determined allometrically by reference to the LAI (see below). Leaf carbon was derived from LAI by way of the specific leaf area parameter, fine root and live stem carbon were set by a ratio to leaf carbon. Live stem carbon was based on a ratio to midsummer leaf carbon and live coarse root carbon was set as a fraction of live stem carbon.

In this application of Biome-BGC, the LAI was comprehensively prescribed spatially and temporally. The seasonal maximum canopy LAI data layer was from the field measurements and ETM+ analysis previously described. For conifer classes, LAI was held constant year round at the summer maximum value. For nonconifer cover classes, a reference seasonal LAI trajectory was developed for each cover class. At NOBS, the leaf on and leaf off dates (Kimball et al., 1997) were used, with 30-day ramps for leaf growth and leaf drop. At HARV, observations of above and below canopy PAR made at the flux tower were used with Beer's Law to estimate daily canopy LAI (Turner et al., 2003). The reference LAI trajectory for each class was then used as a template for that class, and at each $25-\mathrm{m}$ cell a unique seasonal LAI trajectory was created. This was accomplished in each grid cell by determining the ratio of the template LAI to the observed LAI (from ETM + ) at mid growing season and applying that ratio each day to the relevant template LAI to get the full seasonal LAI trajectory for that grid cell. In the shrubland class, total LAI was partitioned to a shrub layer (50\%) and a grass layer (50\%). In the mixed forest class at HARV, the partitioning was $66 \%$ 
Table 2

Results of leaf carbon to nitrogen ratio $(\mathrm{C} / \mathrm{N})$ and fraction of leaf $\mathrm{N}$ in Rubisco (FLNR) calibration based on net primary production (NPP)

\begin{tabular}{|c|c|c|c|c|c|c|}
\hline & $\begin{array}{l}\mathrm{C} / \mathrm{N} \\
\text { (ratio) }\end{array}$ & $\begin{array}{l}\text { FLNR } \\
(\%)\end{array}$ & $N$ & $\begin{array}{l}\text { Mean NPP } \\
\text { observations } \\
\left(\mathrm{gC} \mathrm{m}^{-2}\right. \\
\left.\text { year }^{-1}\right)\end{array}$ & $\begin{array}{l}\text { Mean NPP } \\
\text { simulations } \\
\left(\mathrm{gC} \mathrm{m}^{-2}\right. \\
\left.\text { year }^{-1}\right)\end{array}$ & $\begin{array}{l}\text { RMSE } \\
\left(\mathrm{gC} \mathrm{m}^{-2}\right. \\
\left.\text { year }^{-1}\right)\end{array}$ \\
\hline \multicolumn{7}{|c|}{ Hardwood forest } \\
\hline Deciduous & 24 & 0.14 & 28 & 679 & 667 & 129 \\
\hline Conifer & 37 & 0.08 & 8 & 552 & 544 & 86 \\
\hline Mixed & 18 & 0.11 & 7 & 637 & 625 & 152 \\
\hline \multicolumn{7}{|l|}{ Boreal forest } \\
\hline $\begin{array}{l}\text { Upland Black } \\
\text { Spruce }\end{array}$ & 60 & 0.07 & 25 & 251 & 245 & 66 \\
\hline $\begin{array}{l}\text { Open Black } \\
\text { Spruce }\end{array}$ & 50 & 0.05 & 8 & 181 & 183 & 37 \\
\hline
\end{tabular}

to a hardwood overstory and $33 \%$ to a conifer understory. Ground cover LAI (including bryophytes) was assumed to be 1.0 in the Upland and Open Black Spruce classes at NOBS and was kept constant year round.
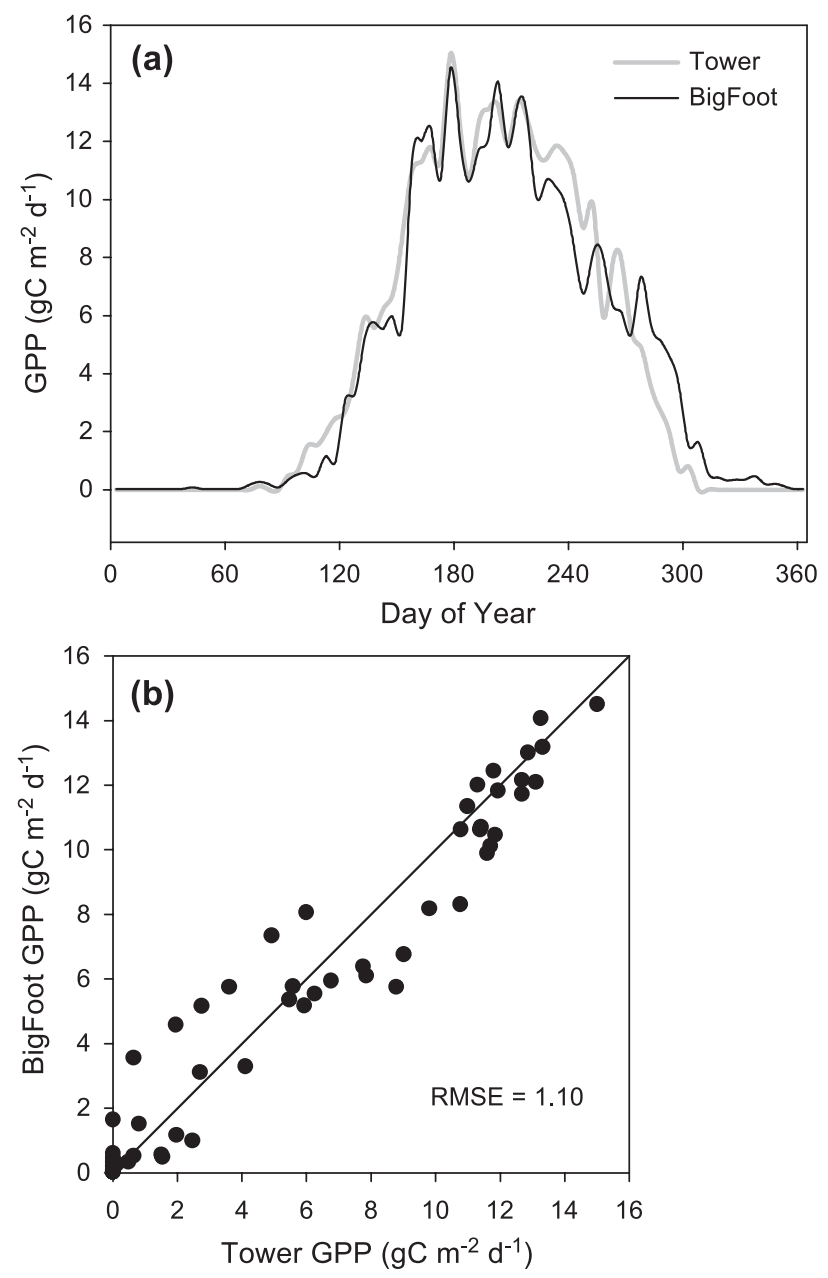

Fig. 4. Gross primary production estimates from an eddy covariance flux tower and as modeled over the $1 \mathrm{~km}^{2}$ cell centered on the flux tower at the Hardwood Forest site: (a) time series, (b) one-to-one comparison.
A model calibration was performed to minimize bias relative to the BigFoot measurements of aboveground net primary production (ANPP). The measured ANPPs were first converted to total NPP using mid range estimates for the ratio of belowground NPP to total NPP by cover class from Gower et al. (1999). The NPPs were then used to calibrate two ecophysiological parameters in the Biome$\mathrm{BGC}$ model - the leaf carbon to nitrogen ratio (leaf $\mathrm{C} / \mathrm{N}$ ) and the fraction of leaf nitrogen as rubisco (FLNR). These variables were used because NPP is the net effect of photosynthesis and autotrophic respiration; FLNR strongly influences modeled photosynthesis whereas leaf $\mathrm{C} / \mathrm{N}$ strongly influences modeled autotrophic respiration. The calibration was performed by cover class for those cover classes with $>5$ ANPP measurements. Only the overstory layer was calibrated in cases of cover classes with two vegetation layers. For each cover class calibrated, the model was first run with default leaf $\mathrm{C} / \mathrm{N}$ and FLNR values at all measurement plot locations (hence using prescribed LAIs), and the Root Mean Square Error (RMSE) determined. The same procedure was then repeated with each combination of leaf
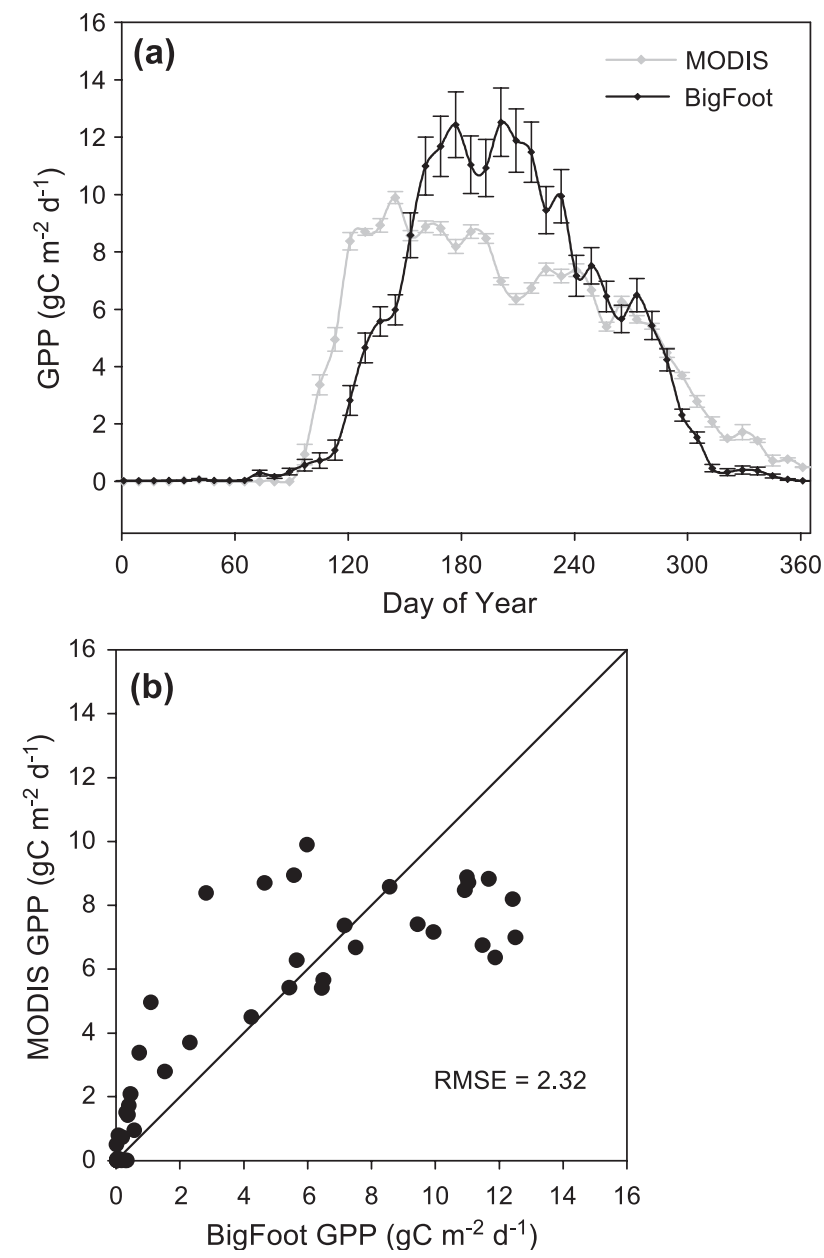

Fig. 5. Gross primary production estimates from MODIS and BigFoot at the Hardwoods site. Values are means and standard deviations for the twentyfive $1 \mathrm{~km}^{2}$ cells in the BigFoot study area. 
Table 3

Annual gross primary production estimates for 2001

\begin{tabular}{llc}
\hline & $\begin{array}{l}\text { Hardwood forest } \\
\left(\mathrm{gC} \mathrm{m}^{-2} \text { year }^{-1}\right)\end{array}$ & $\begin{array}{l}\text { Boreal forest } \\
\left(\mathrm{gC} \mathrm{m}^{-2} \text { year }^{-1}\right)\end{array}$ \\
\hline Flux Tower & 1639 & 812 \\
BigFoot $\left(25 \mathrm{~km}^{2}\right)$ & 1536 & 785 \\
MODIS $\left(25 \mathrm{~km}^{2}\right)$ & 1502 & 1065 \\
\hline
\end{tabular}

$\mathrm{C} / \mathrm{N}$ and FLNR over a prescribed range of values, with increments of 0.01 for FLNR and 1 (HARV) or 5 (NOBS) for $\mathrm{C} / \mathrm{N}$. Ranges of potential leaf $\mathrm{C} / \mathrm{N}$ and FLNR for the different cover classes were determined from the literature (Aber, Reich, \& Goulden, 1996; Dang et al., 1997; Lavigne \& Ryan, 1997; Middleton et al., 1997; White et al., 2000). The combination with the lowest RMSE was selected for use in the spatial mode run. At NOBS, BigFoot ANPP measurements were made in the year 2000, so the calibration model runs were made with flux tower meteorological data for 2000. At HARV the ANPP measurements and meteorological data for the calibrations were from 2001.

The spatial mode run of the model for the MODIS GPP comparisons thus used a spatially and temporally varying LAI, a calibrated leaf C/N and FLNR, and a daily meteorological file based on flux tower measurements. The model was run for one year at each $25 \mathrm{~m}$ cell within the $5 \times 5 \mathrm{~km}$ areas.
For the purposes of corroborating the model GPP estimates with observations at the flux tower, the 1600 daily values for the $1 \mathrm{~km}$ cell occupied by the flux tower were averaged for each day and averaged over the multiple day bins associated with tower-based GPP estimates (Barford et al., 2001; Goulden et al., 1997; Harvard, 2003). For each bin period, a unique relationship of nighttime NEE to air temperature is developed for used in predicting daytime $\mathrm{R}_{\mathrm{e}}$ and hence GPP. The comparisons of tower-based and modeled GPP were evaluated in terms of both the phenological patterns and the absolute magnitudes of GPP during different seasons.

The computer code for the BigFoot version of Biome$\mathrm{BGC}$ (in the $\mathrm{C}$ programming language) and the set of ecophysiological and allometric parameters for all cover types and layers are available from the author upon request.

\subsection{The MODIS GPP Product}

MODIS products are available from the EROS Data Center (EDC, 2003). At the time of this analysis, GPP was not part of the standard suite of products (it will be in the future, Heinsch, Reeves, \& Bowker, 2003). Thus for this study the MODIS GPP/NPP algorithm was run independently but using inputs of land cover, FPAR, LAI, and climate data from the standard MODIS data stream.
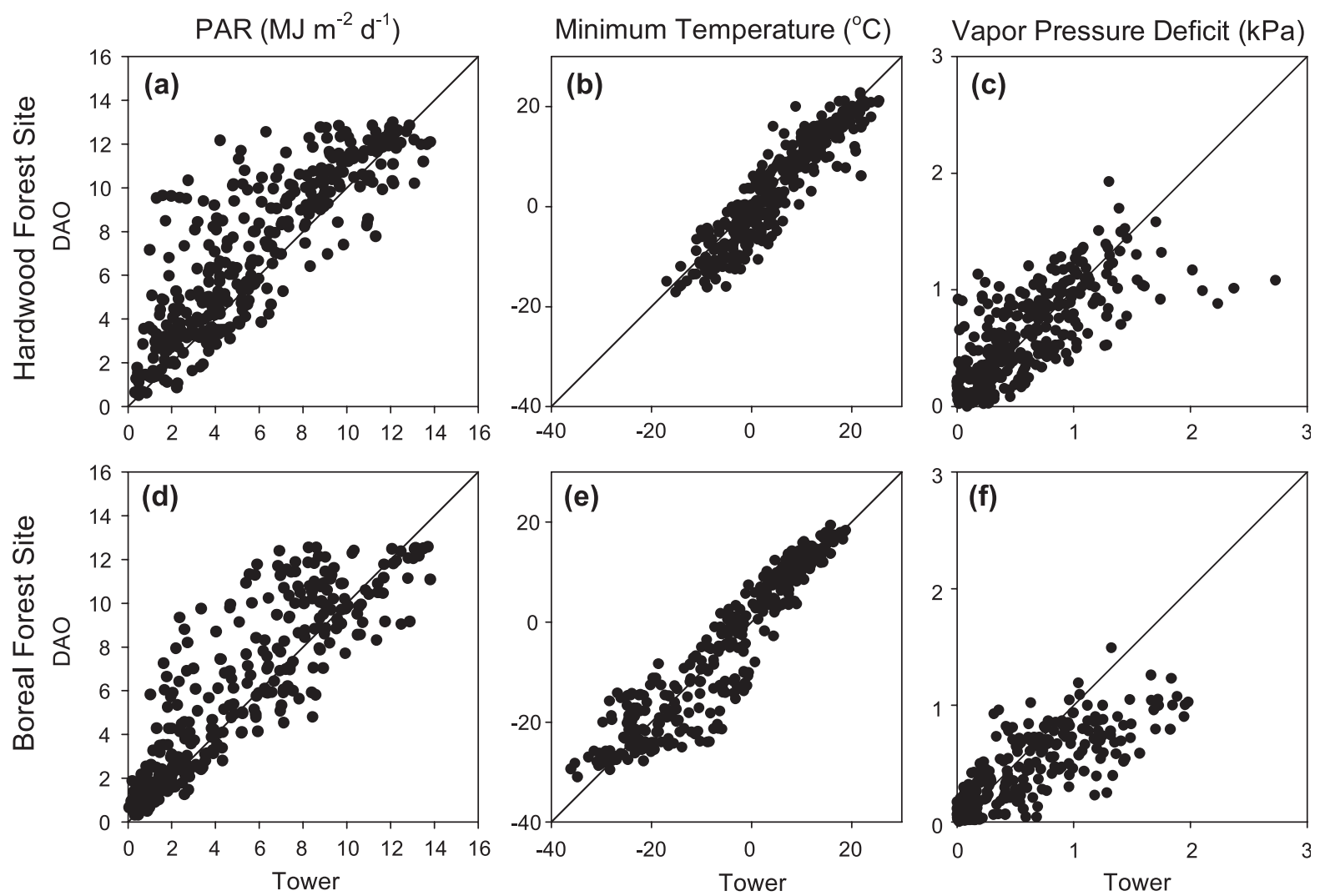

Fig. 6. Comparison of flux tower and DAO meteorological variables used in the MODIS GPP algorithm: (a-c) Hardwood Forest site, (d-f) Boreal Forest site. 
The MODIS products are produced in the Integerized Sinusoidal (ISIN) projection at the 8-day temporal resolution and an approximately $1 \mathrm{~km}$ spatial resolution. The BigFoot GPP analysis in this study is made in the Universal Transverse Mercator (UTM) projection. To minimize artifacts associated with reprojecting the coarse resolution $(1 \mathrm{~km})$ MODIS cells to the fine resolution UTM projection, the modeled GPP data were reprojected to ISIN before spatial aggregation to the MODIS $1 \mathrm{~km}$ grid cells. MODIS GPPs were also transformed from 8-day sums to 8-day means, and units were converted from $\mathrm{kg} \mathrm{ha}^{-1}$ to $\mathrm{gC} \mathrm{m}^{-2}$. The MODIS products have data quality flags and "best" values were used for all comparisons. In two cases there were short gaps in the FPAR values because of sensor malfunction, and these were filled by simple linear interpolation.

MODIS GPPs in this analysis reflect a small change in the MODIS GPP/NPP algorithm that was instituted in the October 2002 reprocessing. That change involved a new parameterization of the VPD scalar (Running et al., 2000) such that a reduction in the scalar begins at a VPD of $650 \mathrm{~Pa}$ and it reaches a value of 0 at a VPD of $2500 \mathrm{~Pa}$. Also note that the MODIS FPAR values are Collection 3.

As a follow-up to the direct comparison of MODIS and ground-based GPP, the specific components of the MODIS GPP algorithm were each examined. Meteorological data from DAO included incident PAR, daily minimum temperature, and VPD. These data for the DAO cell that included the flux tower were compared with meteorological data from the flux tower. FPAR values used in the MODIS algorithm were compared with FPAR values in the ground-based analysis that were derived from LAI. The conversion of the ground-based LAIs to FPAR used a simple Beer's Law approach (Jarvis \& Leverez, 1983).

$$
\operatorname{FPAR}=1-\left(\mathrm{e}^{(\operatorname{LAI} *(-K))}\right)
$$

Where $K$ is the canopy light extinction coefficient, which is an ecophysiological parameter in Biome-BGC. The groundbased FPAR values were averaged to get 8-day mean values over each $1 \mathrm{~km}^{2}$ that could be compared directly to the MODIS values.

The daily light use efficiency $\left(\varepsilon_{\mathrm{g}}\right)$ values were also compared. For the ground-based values, daily $\varepsilon_{\mathrm{g}}$ was the modeled GPP divided by modeled APAR. A daily value was generated by averaging all cells over the $5 \times 5 \mathrm{~km}$ area. For the MODIS $\varepsilon_{\mathrm{g}}$, a weighted average was used based on the proportion of the different land cover types in the $5 \times 5 \mathrm{~km}$ area (each cover type has its own daily $\varepsilon_{\mathrm{g}}$ ).

\section{Results}

\subsection{Hardwood forest (HARV) site}

In the land cover classification for the HARV site, 56\% of the land was deciduous broadleaf forest, $12 \%$ was coniferous forest and 20\% was mixed forest (Fig. 1a). Mid season maximum LAI had a mean value of 4.9 (Cohen et al., 2003). The climate in 2001 was relatively dry $(85 \mathrm{~cm}$ vs. the 10-year average of $112 \mathrm{~cm})$. However, there was a corresponding increase in PAR $(6 \%$ higher than the 10-year average).

The selected $\mathrm{C} / \mathrm{N}$ and FLNR for the deciduous broadleaf class were 24 and 0.14 respectively and the associated RMSE was $129 \mathrm{gC} \mathrm{m}^{-2}$ year $^{-1}, 19 \%$ of the mean observed NPP (Table 2). RMSEs for the conifer and mixed clover classes were $16 \%$ and $24 \%$ of the respective mean NPP values. There was no appreciable bias between the simulations and the observations for any of the cover types. The comparison of flux tower GPP with BigFoot GPP aggregated temporally over the same bin periods and spatially over the $1 \mathrm{~km}$ grid cell containing the flux tower (the approximate footprint) showed good agreement (Fig. 4) with an RMSE of $1.1 \mathrm{gC} \mathrm{m}^{-2}$ day $^{-1}$ (14\% of the mean). The BigFoot GPP was consistently about $2 \mathrm{gC} \mathrm{m}^{-2}$ day $^{-1}$ higher towards the end of the growing season.
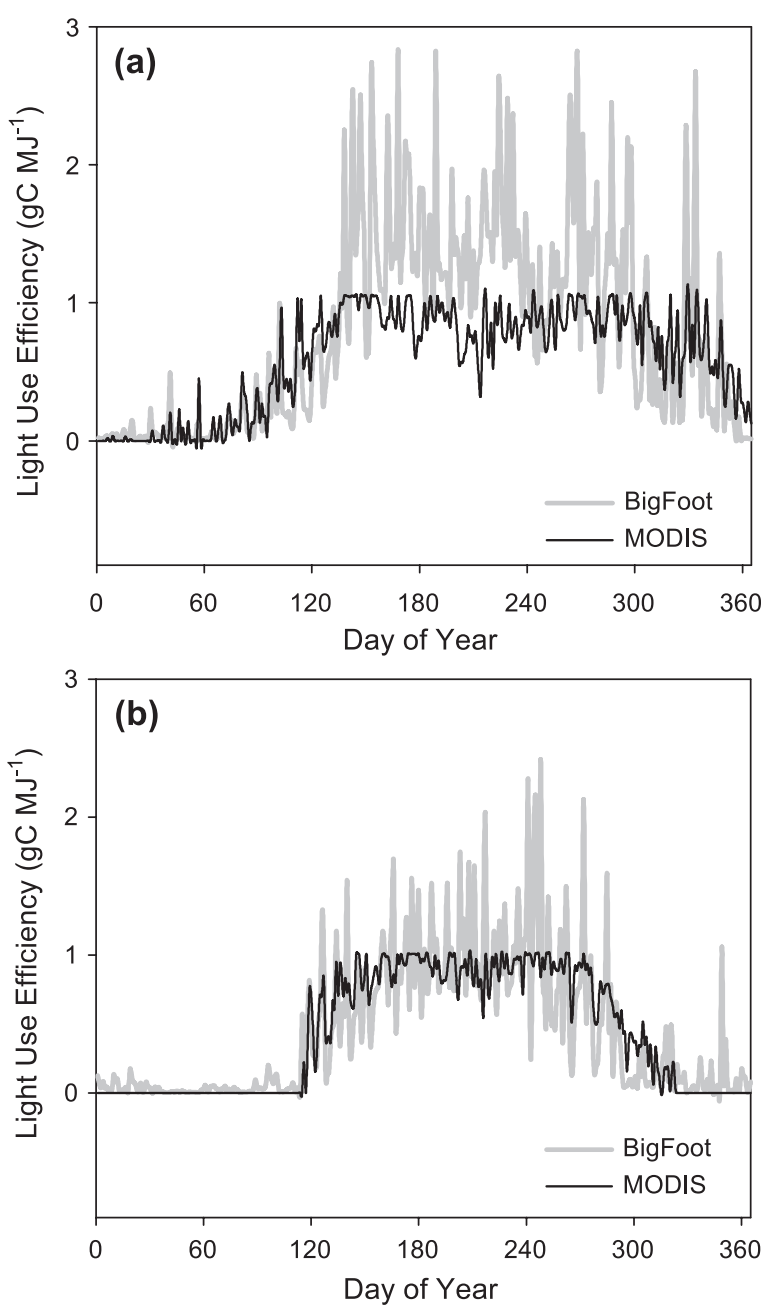

Fig. 7. Daily light use efficiency from MODIS and BigFoot. Values are means for the twenty-five $1 \mathrm{~km}^{2}$ cells in the study area: (a) Hardwood Forest site, (b) Boreal Forest site. 

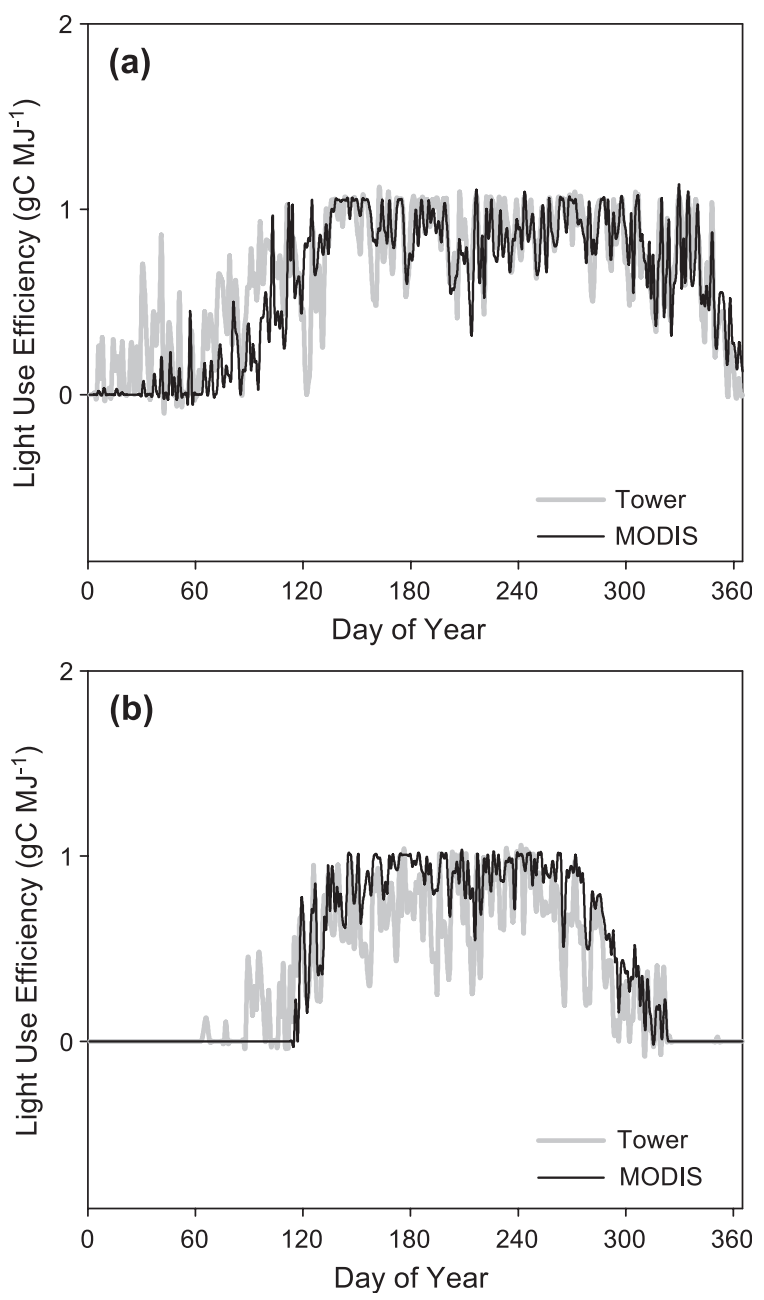

Fig. 8. Comparison of MODIS daily light use efficiency based on DAO meteorological data and flux tower meteorological data: (a) Hardwood Forest site, (b) Boreal Forest site.

The comparison of mean MODIS GPP over the $25 \mathrm{~km}^{2}$ with the BigFoot GPP over that area showed the MODIS GPP with a high bias (i.e. MODIS $>$ BigFoot) of $\sim 4 \mathrm{gC}$ $\mathrm{m}^{-2}$ day $^{-1}$ in April and May, a low bias $\left(2-5 \mathrm{gC} \mathrm{m}^{-2}\right.$ day $^{-1}$ ) in June through August, and good agreement in September and October (Fig. 5). The comparison also showed an earlier initiation of the growing season and a later cessation of the growing season in the MODIS product. The total annual GPP averaged over the $25 \mathrm{~km}^{2}$ area was $1502 \mathrm{gC} \mathrm{m}^{-2}$ year $^{-1}$ for the MODIS product and $1536 \mathrm{gC}$ $\mathrm{m}^{-2}$ year $^{-1}$ for the BigFoot product (Table 3). Variability among the twenty-five $1-\mathrm{km}^{2}$ cells was consistently greater in the BigFoot GPP (Fig. 5a).

Comparisons of flux tower meteorological data with MODIS Data Assimilation Office (DAO) meteorological data showed generally good agreement for VPD and minimum temperature, whereas the DAO PAR had a high bias (Fig. 6a-c). The BigFoot $\varepsilon_{\mathrm{g}}$ was usually higher and had higher variability than the MODIS $\varepsilon_{\mathrm{g}}$ (Fig. 7a). The average BigFoot $\varepsilon_{\mathrm{g}}$ for the June to August period was $1.5 \mathrm{gC} \mathrm{MJ}^{-1}$

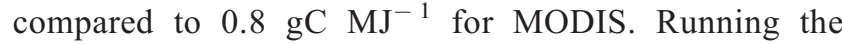
MODIS GPP algorithm with flux tower meteorological data rather than DAO data did not have much effect on $\varepsilon_{\mathrm{g}}$ (Fig. 8a). The FPAR from MODIS and BigFoot both showed seasonality and maximum values near 0.9 but the MODIS FPAR began increasing earlier in the growing season and remained high in the later part of the year (Fig. 9a).

\subsection{Boreal forest site (NOBS)}

Land cover at the NOBS site (Fig. 1b) was predominantly Upland Black Spruce (45\%) and Open Black Spruce $(25 \%)$. Small areas of Deciduous Broadleaf $(6 \%)$, Shrubland $(12 \%)$, and Wetlands $(9 \%)$ were also present. Mean LAI (canopy + ground cover) over the $5 \times 5 \mathrm{~km}$ area was 4.1 (Cohen et al., 2003), with highest values in the Upland Black Spruce class. The climate at the NOBS site in 2001 closely approximated the 8-year average. Mean annual temperature was $-0.26{ }^{\circ} \mathrm{C}$ compared to the mean for the
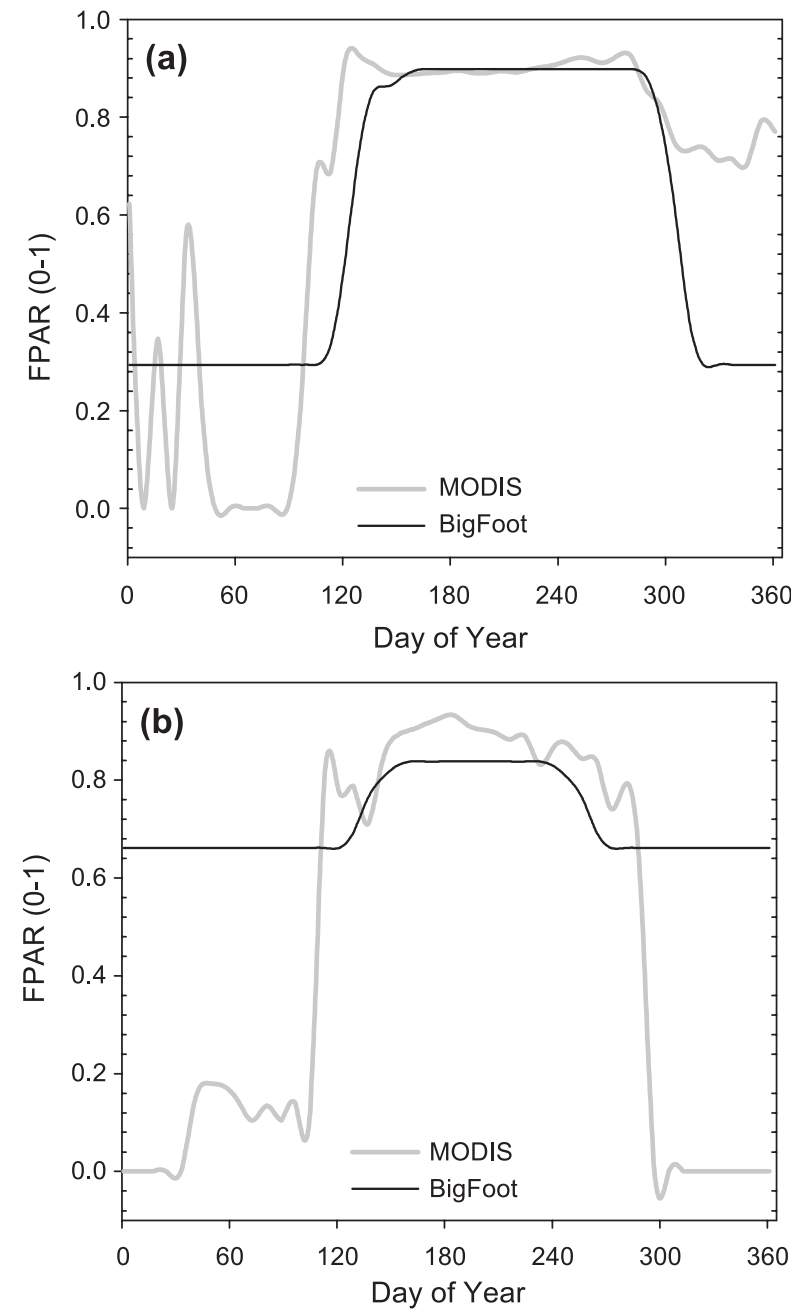

Fig. 9. Seasonal FPAR trajectories from MODIS and BigFoot. MODIS values are the means of all "best" estimates for each period. BigFoot values are means for all $251 \mathrm{~km}^{2}$ cells: (a) Hardwood Forest site, (b) Boreal Forest site. 
previous 8 years of $-1.87{ }^{\circ} \mathrm{C}$ and total precipitation was $26.3 \mathrm{~cm}$ compared to $31.8 \mathrm{~cm}$ for previous 8 years.

In the calibration procedure, the selected $\mathrm{C} / \mathrm{N}$ and FLNR were similar for the two Black Spruce dominated classes (Table 2). The RMSE after the calibration was $27 \%$ of the mean NPP for the Upland Black Spruce class and 20\% of the mean for the Open Black Spruce class. There was little bias between simulations and observations in the mean NPPs. Tower-based and BigFoot GPPs showed good agreement (Fig. 10) in terms of seasonality, however, there was a slight low bias in the BigFoot product that was particularly apparent in May.

In the MODIS/BigFoot comparison there was a consistent high bias $\left(1-3 \mathrm{gC} \mathrm{m}^{-2}\right.$ day $\left.^{-1}\right)$ in the MODIS product (Fig. 11), with annual GPP 36\% higher than for the BigFoot product (Table 3). The seasonal maximum value in both products occurred late in June. The maximum for the MODIS product was $11 \mathrm{gC} \mathrm{m}^{-2}$ day $^{-1}, 2 \mathrm{gC} \mathrm{m}^{-2}$ day $^{-1}$ higher than the maximum BigFoot value and the tower values. There was good agreement with regard to the beginning and the end of the growing season.
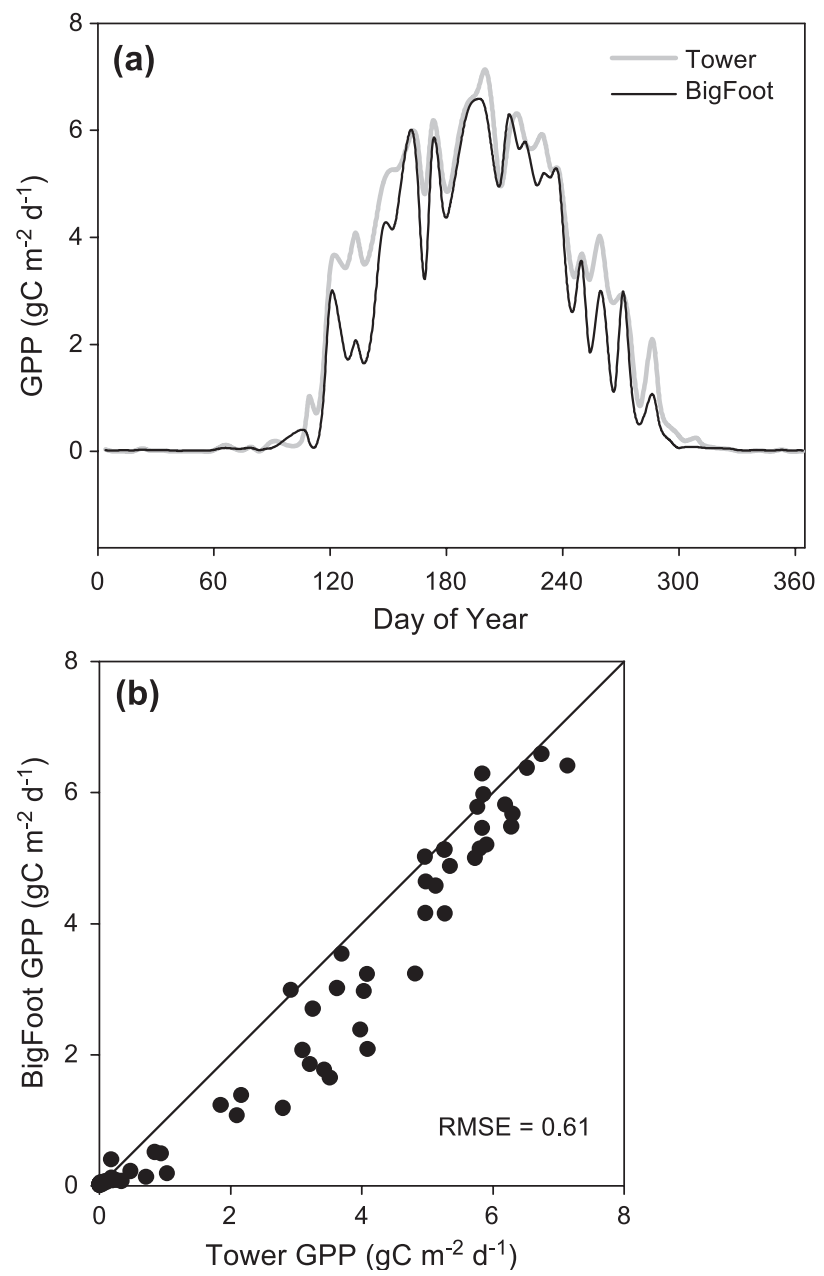

Fig. 10. Gross primary production estimates from an eddy covariance flux tower and as modeled over the $1 \mathrm{~km}^{2}$ cell centered on the flux tower at the Boreal Forest site: (a) time series comparison, (b) one-to-one comparison.
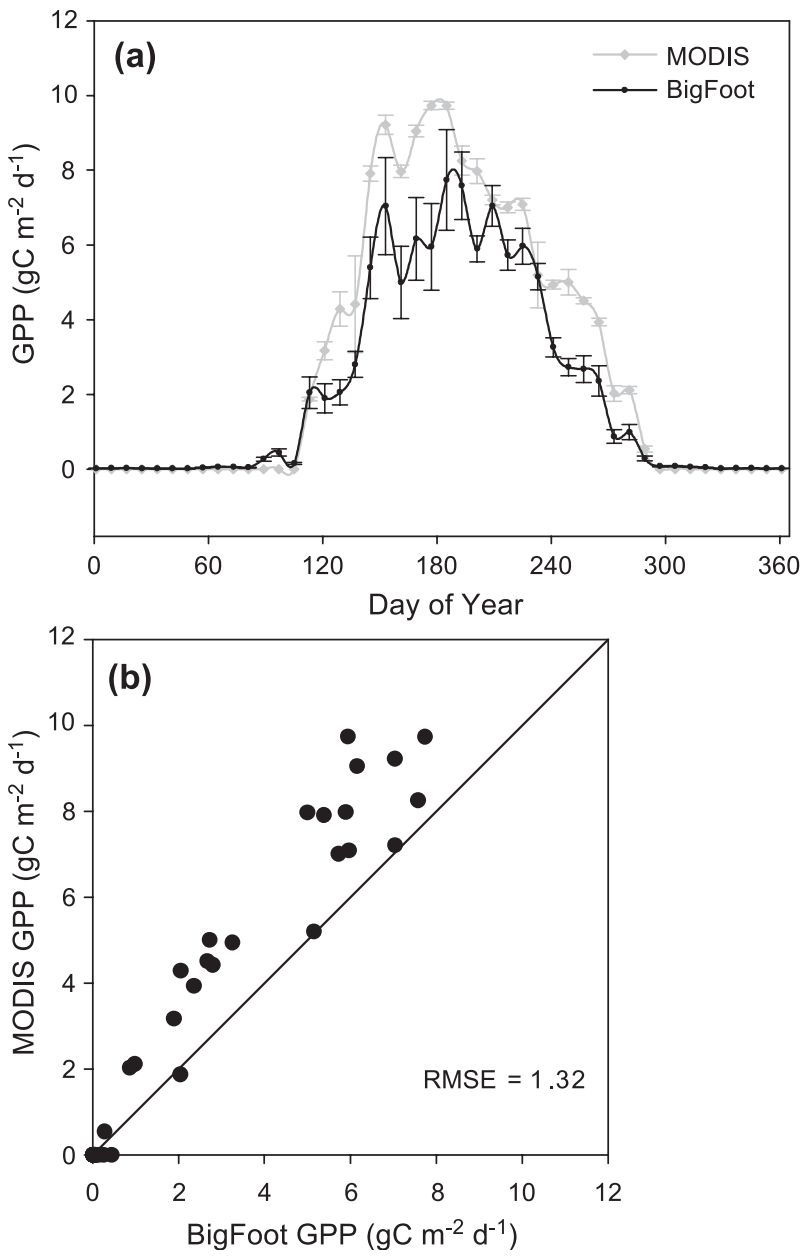

Fig. 11. Gross primary production estimates from MODIS and BigFoot at the Boreal Forest site. Values are means and standard deviations for the twenty-five $1 \mathrm{~km}^{2}$ cells in the BigFoot study area.

The site-average maximum daily $\varepsilon_{\mathrm{g}}$ from MODIS was $1.0 \mathrm{gC} \mathrm{MJ}^{-1}$ whereas the site average daily $\varepsilon_{\mathrm{g}}$ from BigFoot was as high as $2.0 \mathrm{gC} \mathrm{MJ}^{-1}$ (Fig. 7b). The DAO daily Tmin values were similar to those measured at the flux tower but VPD showed a low bias at high values and PAR showed the same high bias as at the Hardwood Forest site (Fig. 6d-f). Substituting flux tower meteorological data for DAO values resulted in consistently lower $\varepsilon_{\mathrm{g}}$ values because of the higher VPDs (Fig. 8b). FPAR values were near 1.0 for both data sets during mid growing season with slightly lower values from BigFoot (Fig. 9b). The MODIS FPAR showed a distinct seasonality that was not found in the BigFoot FPAR trajectory.

\section{Discussion}

\subsection{Assessment of BigFoot GPP products}

The BigFoot GPP scaling approach seeks to produce a well-documented series of products that take maximum 
advantage of a wide array of ground and satellite measurements. The BigFoot products include GPP at a spatial and temporal resolution compatible with the MODIS Land Science Team GPP product. The carbon cycle process model (Biome-BGC) on which the BigFoot GPP scaling approach is based uses observations of land cover, LAI and meteorological parameters as inputs, measurements of NPP for model calibration, and measurements of GPP for model validation.

Specification of land cover delivers information on the appropriate set of ecophysiological constants, which reflects considerable previous research on these parameters for different plant functional types (see White et al., 2000). The algorithms within the model that represent physiological processes such as photosynthesis and respiration also reflect a large body of field and laboratory ecophysiological research (Sellers, Dickinson et al., 1997). LAI is well recognized as an important control on GPP/NPP in boreal and temperate forests (Bonan, 1993; Woodward, 1987) and it is often prescribed in process model applications (Hunt et al., 1996; Williams et al., 2001). Prescribing LAI spatially and temporally, as was done here, is a significant benefit over prognostic modeling of LAI (e.g. Heimann et al., 1998), which has many limitations. The calibration of key model parameters with NPP observations serves to prevent a strong bias in modeled NPP. Lastly, the comparisons of modeled and measured GPP over a complete growing season permits an evaluation of model performance in a specific environment.

A central assumption in the BigFoot scaling approach is that the benefits of using the observational data are greater than the uncertainties in the observations and in related propagation of uncertainty in the model. The uncertainties in the BigFoot land cover and spatial patterns in LAI are relatively small (Cohen et al., 2003) and seem unlikely to have a large impact on overall GPP uncertainty. The temporal variation in LAI is more problematic because a more systematic scheme for monitoring the seasonal variation in LAI/FPAR is needed. Micrometeorological specialists produce the meteorological data used to drive the model and thus quality assurance is relatively high. Less than $20 \%$ of the days at either site required filling in missing data with measurements from elsewhere. The effectiveness of the model itself has been documented to some degree with regard to NPP in boreal (Kimball et al., 2000, 1999, 1997) and temperate (Running, 1994) forests. The used of binned GPP data at the tower makes it difficult to closely evaluate the effectiveness of modeled GPP responses to day-to-day variation in meteorology but the model output is clearly tracking most of the oscillations during the growing season.

At the HARV site, the high bias at the end of the growing season (Fig. 4a) is probably related to a decrease in light use efficiency observed in the tower data (Turner et al., 2003) that is not present in the model. The mechanism is possibly a retranslocation of nitrogen from the foliage, which is not specified in the model. The BigFoot GPP product also misses a small pulse of GPP early in the growing season that is associated with the flush in vernal herbs (Braun, 1950). The prescribed LAI trajectory used to produce the BigFoot GPP product is based on canopy LAI and thus did not include this feature.

At the NOBS site, there is also good agreement in the short-term oscillations of the binned GPP values. The model does well with the beginning and end of the growing season because of the strong signal in the air temperature. The small low bias may reflect an error in the assumed ratio of belowground to aboveground production. That ratio is not well constrained by measurements (Gower et al., 1999) and if it were increased in the estimations of NPP used in the calibration, the calibration procedure would have selected a lower foliar $\mathrm{C} / \mathrm{N}$, with a corresponding increase in GPP.

With regard to the NPP and GPP measurements used in the calibration and validation, it must be recognized that they are not absolute reference points. In principal NPP is simply the measurement of biomass production over the course of a year, but in practice there are myriad difficulties and great cumulative uncertainties (Clark et al., 2001; Gower et al., 2001). As noted, the uncertainty for belowground production was much greater than that for aboveground production since only the latter was measured. Estimation of GPP from eddy covariation flux towers is also fraught with uncertainties, notably the estimation of ecosystem respiration (Goulden et al., 1996a; Turner et al., 2003). Nevertheless, the data in this analysis are the highest quality data available, and provide a set of internally consistent constraints on model behavior.

The BigFoot FPAR values that were compared to those used in the MODIS algorithm were certainly rudimentary at this point because of the simplicity of the Beer's Law formulation used to convert LAI to FPAR. The simple formulation of Beer's Law was used to derive FPAR in this study because that is the FPAR algorithm in the BiomeBGC model, and here the modeled APAR was used in combination with the modeled GPP to estimate $\varepsilon_{\mathrm{g}}$. Particularly in the boreal forest, an equation relating LAI to FPAR that accounted for solar zenith angle and clumping factors would have produced more accurate estimates (Chen, Rich, Gower, Norman, \& Plummer, 1997). A 30-day ramp for leaf-on in the case of the boreal hardwood forest cover type is also overly simplistic. BigFoot FPAR products under development will be based on direct FPAR measurements using an array of below canopy PAR sensors.

The issue of matching the spatial scale of the NPP observations and the BigFoot simulations must also be recognized as a limitation in linking of the two. The BigFoot observations of NPP were made at approximately the scale of the BigFoot grid cell, i.e. 1 NPP plot covered approximately one $25 \times 25 \mathrm{~m}$ grid cell. However, in using the NPP measurements for model calibration, the model value chosen was simply the one with its cell center nearest to the center of the NPP measurement plot. The plot centers were located with a Global Positioning System instrument, nom- 
inally accurate to $0.5 \mathrm{~m}$. The georegistration of the satellite imagery upon which the BigFoot land cover and LAI estimates were based was on the order of one $25-\mathrm{m}$ cell. Thus there was undoubtedly some mismatch between the imagery and the ground measurements. Generally, the scale of the heterogeneity at these sites was greater than $25 \mathrm{~m}$, so these mismatches were not large.

The mismatch between the actual flux tower footprint (not specifically estimated in this study) and the $1 \mathrm{~km}^{2}$ footprint approximation used in the comparisons to BigFoot GPP is also an issue. There are clear indications in the flux tower data of different mean NEE values from different wind directions and these differences can be related to differences in vegetation (Goulden et al., 1996b). The wind speed and direction vary continuously, yet the Biome-BGC model used in the scaling has a daily time step. Thus the tracking of actual footprint by simulated footprint is quite limited. Nevertheless, considering the obvious heterogeneity in land cover and LAI in the vicinity of these towers, averaging the model outputs for the $1 \mathrm{~km}^{2}$ around the tower is still probably a significant improvement over comparison to just one BigFoot $25 \mathrm{~m}$ grid cell simulation.

\subsection{Assessment of MODIS GPP Products}

Estimates of GPP are among the highest order products of MODIS in that they rely upon other MODIS productsland cover and FPAR - and on accurate values of daily $\downarrow$ PAR, temperature, and humidity from DAO. The product also relies on the correct parameterization of the light use efficiency for GPP (Running et al., 2000). This list of inputs to the GPP algorithm suggests a great deal of uncertainty in the MODIS GPP estimates, and emphasizes the importance of validation. Some of the key features for evaluating the MODIS GPP product are its accuracy with respect to summer maximum values, the dates of growth initiation and cessation, and the annual summed GPP.

The maximum MODIS GPP, averaged spatially over the $25-\mathrm{km}^{2}$ study area and temporally over 8-day periods, was $11 \mathrm{gC} \mathrm{m}^{-2}$ day $^{-1}$ at the HARV site and close to $10 \mathrm{gC}$ $\mathrm{m}^{-2}$ day $^{-1}$ at the NOBS site. These maxima occurred near the summer solstice when PAR was maximal (11-12 MJ day $\left.{ }^{-1}\right)$, FPAR was maximal $(>0.9)$, and there were no constraints on $\varepsilon_{\mathrm{g}}$ from Tmin and VPD. The maxima in the BigFoot GPP trajectories occurred at about the same time of year but were $20 \%$ lower at HARV and $20-40 \%$ higher at NOBS.

The dominant factors in the MODIS GPP algorithm that accounted for the differences between MODIS and BigFoot in maximum GPP related more to $\downarrow$ PAR and $\varepsilon_{\mathrm{g}}$ than to FPAR. The DAO $\downarrow$ PAR values tend to be higher that the BigFoot values, which contributed to the MODIS overestimate of maximum GPP at NOBS. However, the MODIS underestimate of the maximum GPP at HARV would be worse with use of the BigFoot $\downarrow$ PAR data.
The MODIS $\varepsilon_{\mathrm{g}}$ values, even under unstressed conditions, were on average lower than BigFoot values. The strongest determinant of that difference was much higher values of $\varepsilon_{\mathrm{g}}$ on overcast days in the BigFoot product. Observations of GPP and APAR at the two flux towers show that $\varepsilon_{g}$ decreases significantly at the highest APARs (Turner et al., 2003). Because the photosynthesis algorithm in the Biome-BGC model uses a standard asymptotic relationship of photosynthesis to irradiance, this ecophysiological response is built into the BigFoot scaling approach. The MODIS underestimate of maximum GPP at HARV is also related to the VPD scalar, which appears to be overly sensitive. The current algorithm begins reducing $\varepsilon_{\mathrm{g}}$ above VPD of $650 \mathrm{~Pa}$ (daytime average) but observations of leaf level photosynthesis (Bassow \& Bazzaz, 1998) and canopy level GPP (Turner et al., 2003) at HARV do not indicate sensitivity to VPDs $<1500 \mathrm{~Pa}$.

Another limitation in the MODIS $\varepsilon_{\mathrm{g}}$ values is an apparent underestimation of the maximum $\varepsilon_{\mathrm{g}}$. Observations at the flux towers suggest maximum $\varepsilon_{\mathrm{g}}$ values on the order of $2 \mathrm{~g}$ $\mathrm{C} \mathrm{MJ}^{-1}$ at NOBS and $3 \mathrm{~g} \mathrm{C} \mathrm{MJ}^{-1}$ at HARV (Turner et al., 2003). These compare with the MODIS algorithm values of about $1.0 \mathrm{gC} \mathrm{MJ}^{-1}$ in these cover types. These values are comparable to what is observed on days with high APAR at the flux towers (Turner et al., 2003). However, on overcast days (APAR below about $6 \mathrm{MJ} \mathrm{m}^{-2}$ day $^{-1}$ ) the $\varepsilon_{\mathrm{g}}$ increases significantly.

Regarding the seasonality of GPP, the rapid increase in the MODIS FPAR in early spring at HARV tended to drive an increase in the MODIS GPP that was too rapid relative to the BigFoot (and flux tower) GPP increase. The BigFoot FPAR, based on observations of PAR above and below the canopy at the flux tower, lagged significantly behind the MODIS FPAR during greenup. At the end of the growing season, MODIS GPP was maintained at a higher rate than is indicated by the BigFoot trajectory. This effect appears to be driven by the failure of the MODIS FPAR to decrease in October, November and December. At NOBS, the seasonality in GPP is tightly regulated by temperature, and the MODIS approach with its Tmin scalar successfully captures it.

At NOBS, the MODIS annual GPP was $1065 \mathrm{gC} \mathrm{m}^{-2}$ year $^{-1}$ compared to 785 for the BigFoot product. These compare with $812 \mathrm{gC} \mathrm{m}^{-2}$ year $^{-1}$ for the flux tower. At the HARV site there were offsetting errors at the middle and the ends of the growing season so the MODIS GPP (1502 gC $\mathrm{m}^{-2}$ year $^{-1}$ ) was more similar to the BigFoot (1536 gC $\mathrm{m}^{-2}$ year $\left.^{-1}\right)$ and flux tower $\left(1639 \mathrm{gC} \mathrm{m}^{-2}\right.$ year $\left.^{-1}\right)$ values.

\subsection{Implications for the MODIS GPP algorithm}

The key components of the MODIS Land Science Team GPP algorithm are the DAO climate data, the MODIS FPAR, and the parameterization of the light use efficiency look up table (Running et al., 2000). This study has revealed a variety of differences between those components as implemented in 2001 and the ground-based measurements. 
Because of the comprehensive archiving of MODIS data, reprocessing of data for specific algorithms will be possible at any time during the expected 5-year lifetime of the sensor. Thus, it is worth considering possibilities for improvements.

As far as the DAO data, there will always be limitations in the degree to which the General Circulation Model-based estimates agree with ground measurements at particular sites because of the coarse scale of the DAO model outputs $(\sim 100 \mathrm{~km})$. The differences found in this analysis are related to this mismatch in scale as well as possible limitations of the DAO product. The NOBS site is relatively flat over multiple DAO $1^{\circ}$ cells, so the mismatch in scale would be expected to be less of an issue. In any case, more comprehensive validations studies of the DAO product are being made and it is expected that improvements will be made with time.

The MODIS FPAR product captured the high mid growing season values at the HARV and NOBS sites, i.e. in both cases FPAR was near 0.8 or higher across most of the landscape in the MODIS and BigFoot products. Outside the growing season, there appears to be problems with high values at HARV and low values at NOBS. However, these have limited effects on the MODIS GPP product because the PAR and the minimum temperature scalar are usually low in any case. The MODIS FPAR has a strong spring green-up signal at the HARV site and it appears to achieve its summer maximum somewhat earlier than is indicated by the ground measurements. This causes a corresponding overestimation of GPP early in the growing season. The MODIS FPAR does not show the expected dramatic decrease observed late in the growing season at HARV, which also causes some overestimation of GPP. Interestingly, the MODIS LAI product does show the autumn leaf drop (Cohen et al., 2003), so perhaps the FPAR algorithm could be modified to capture this same effect.

The MODIS $\varepsilon_{\mathrm{g}}$ parameterization is perhaps the most amenable of the algorithm's components to modification because it relies on a simple look-up table approach. The threshold and maximum for the VPD scalar have already been modified once. The original biome-specific $\varepsilon_{\mathrm{g}}$ maxima and scalar parameterizations were based on model outputs rather than observations of $\varepsilon_{\mathrm{g}}$ and there is significant potential for improvement now that an extensive global network of eddy covariance flux towers is in place (Running et al., 1999). Observations at the HARV and NOBS flux towers suggest higher maximum values for $\varepsilon_{\mathrm{g}}$ than are being used in the MODIS algorithm, and a fall off in $\varepsilon_{\mathrm{g}}$ at high APAR values (Turner et al., 2003). As generalizations about $\varepsilon_{\mathrm{g}}$ become possible across multiple flux towers and multiple years in each biome, new parameterization can be implemented in the MODIS algorithm. The possibility for remote sensing of $\varepsilon_{\mathrm{g}}$ using high spectral resolution sensors is also being investigated (Barton \& North, 2001; Gamon, Penuelas, \& Field, 1992).

Estimates of GPP from MODIS satellite imagery are of interest from both a relative and an absolute perspective. For the purposes of assessing interannual variation in GPP at a particular place, or globally, it is the difference from year to year (i.e. the relative value) and its relationship to climatic variables and disturbance regimes that is most important. Even if there are significant errors in the satellite-based GPP product, changes in the annual sum from year to year provide useful information. However, to better understand the global carbon cycle it is desirable to capture the absolute values of global GPP in any given year and the magnitude of the differences between years. Thus it will be important to continue improving the relevant algorithms and validating the products with ground-based measurements and modeling.

\section{Conclusions}

The data stream provided by the MODIS sensor, and the associated system for data processing and archiving, has initiated a new era in Earth observations and monitoring. The effort to validate MODIS-based products with ground observations introduces many significant scaling issues; and for GPP, an approach based on a spatially distributed ecosystem process model provides a means to comprehensively assess the product as well as the algorithm. At a temperate zone hardwood forest site and a boreal conifer forest site, the MODIS GPP product for 2001 showed the expected seasonality but analyses of the components of the algorithm reveal a variety of limitations. The parameterization of the light use efficiency component of the MODIS GPP algorithm is particularly amenable to improvement based on observations of light use efficiency at eddy covariance flux towers.

\section{Acknowledgements}

This study was funded by NASA through the Terrestrial Ecology Program. Funding at tower sites was provided by the Department of Energy and NASA. Data available through AmeriFlux, FLUXNET and the ORNL DAAC Mercury Data System were essential to this study.

\section{References}

Aber, J. D., Reich, P. B., \& Goulden, M. L. (1996). Extrapolating leaf $\mathrm{CO}_{2}$ exchange to the canopy: A generalized model of forest photosynthesis validated by eddy correlation. Oecologia, 106, 267-275.

AmeriFlux, 2003. http://public.ornl.gov/ameriflux/Participants/Sites/Map/ index.cfm.

Amthor, J. S. (2000). The McCree-de Wit-Penning de Vries-Thornley respiration paradigms: 30 years later. Annals of Botany, 86, 1-20.

Barford, C. D., Wofsy, S. C., Goulden, M.L.M.J.W., Pyle, E. H., Urbanski, S. P., Hutyra, L., Saleska, S. R., Fitzjarrald, D., \& Moore, K. (2001). Factors controlling long- and short-term sequestration of atmospheric $\mathrm{CO}_{2}$ in a mid-lattitude forest. Science, 294, 1688-1691.

Barton, C. V. M., \& North, P. R. J. (2001). Remote sensing of canopy light use efficiency using the photochemical reflectance index model and sensitivity analysis. Remote Sensing of Environment, 78, 264-273. 
Bassow, S. L., \& Bazzaz, F. A. (1998). How environmental conditions affect canopy leaf-level photosynthesis in four deciduous tree species. Ecology, 79, 2660-2675.

BigFoot, 2003. http://www.fsl.orst.edu/larse/bigfoot/index.html.

Bisbee, K. E., Gower, S. T., \& Norman, J. M. (2003). comparison of carbon and light use dynamics of two boreal black spruce forest communities. Ecosystems (in press).

Bonan, G. B. (1993). Importance of leaf area index and forest type when estimating photosynthesis in boreal forests. Remote Sensing of Environment, 43, 303-314.

Braun, E. L. (1950). Deciduous forests of Eastern North America. New York: Hafner.

Campbell, J. L., Burrows, S., Gower, S. T., \& Cohen, W. B. (1999). BigFoot: Characterizing land cover, LAI, and NPP at the landscape scale for EOS/MODIS validation. Field manual version 2.1. Oak Ridge, TN: Environmental Sciences Division, Oak Ridge National Laboratory.

Chen, J. M., Rich, P. M., Gower, S. T., Norman, J. M., \& Plummer, S. (1997). Leaf area index of boreal forests: Theory, techniques, and measurements. Journal of Geophysical Research, 102, 29429-29444.

Clark, D. A., Brown, S., Kicklighter, D. W., Chambers, J. Q., Thomlinson, J. R., Ni, J., \& Holland, E. A. (2001). Measuring net primary production in forests: Concepts and field methods. Ecological Applications, 11, $356-370$.

Cohen, W. B., Maiersperger, T. K., Gower, S. T., Turner, D. P., \& Fassnacht, K. (2003). Empirical modeling of biophysical variables using Landsat ETM+ data. Remote Sensing of Environment, 84, 561-571.

Cohen, W. B., Maiersperger, T. K., Gower, S. T., Turner, D. P., \& Running, S. W. (2003). Comparisons of land cover and LAI estimates derived from ETM+ and MODIS for four sites in North America: A quality assessment of provisional MODIS products. Remote Sensing of Environment $88,233-255$.

Coops, N. C., Waring, R. H., Brown, S. R., \& Running, S. W. (2001). Comparisons of predictions of net primary production and seasonal patterns in water use derived with two forest growth models in Southwestern Oregon. Ecological Modelling, 142, 61-81.

Dang, Q. L., Margolis, H. A., Mikailou, S., Coyea, M. R., Collatz, G. J., \& Walthall, C. L. (1997). Profiles of photosynthetically active radiation, nitrogen and photosynthetic capacity in the boreal forest: Implications for scaling from leaf to canopy. Journal of Geophysical Research, 102 , $28845-28859$.

EDC (2003). USGS EROS Data Center http://redhook.gsfc.nasa.gov/ $\sim$ imswww/pub/imswelcome/plain.html.

Falge, E., Baldocchi, D., Tenhunen, J., et al (2002). Seasonality of ecosystem respiration and gross primary production as derived from FLUXNET measurements. Agricultural and Forest Meteorology, 113, $53-74$.

Frolking, S., Goulden, M. L., Wofsy, S. C., et al (1996). Modelling temporal variability in the carbon balance of a spruce moss boreal forest. Global Change Biology, 2, 343-366.

Gamon, J. A., Penuelas, J., \& Field, C. B. (1992). A narrow-waveband spectral index that tracks diurnal changes in photosynthetic efficiency. Remote Sensing Environment, 41, 35-44.

Goulden, M. L., Daube, B. C., Fan, S.-M., Sutton, D. J., Bazzaz, A., Munger, J. W., \& Wofsy, S. C. (1997). Physiological responses of a black spruce forest to weather. Journal of Geophysical Research, 102, 28987-28996

Goulden, M. L., Munger, J. W., Fan, S., Daube, B. C., \& Wofsy, S. C. (1996a). Measurements of carbon sequestration by long-term eddy covariance: Methods and a critical evaluation of accuracy. Global Change Biology, 2, 169-182.

Goulden, M. L., Munger, J. W., Fan, S.-M., Daube, B. C., \& Wofsy, S. C. (1996b). Exchange of carbon dioxide by a deciduous forest: Response to interannual climate variability. Science, 271, 1576-1578.

Goulden, M. L., Wofsy, S. C., Harden, J. W., Trumbore, S. E., Crill, P. M., Gower, S. T., Fries, T., Daube, B. C., Fan, S.-M., Sutton, D. J., Bazzaz, A., \& Munger, J. W. (1998). Sensitivity of boreal forest carbon balance to soil thaw. Science, 279, 214-217.
Gower, S. T., Krankina, O., Olson, R. J., Apps, M., Linder, S., \& Wang, C. (2001). Net primary production and carbon allocation patterns of boreal forest ecosystems. Ecological Applications, 11, 1395-1411.

Gower, S. T., Kucharik, C. J., \& Norman, J. M. (1999). Direct and indirect estimation of leaf area index, fAPAR and net primary production of terrestrial exosystems. Remote Sensing of Environment, 70, 29-51.

Ham, J. M., \& Knapp, A. K. (1998). Fluxes of $\mathrm{CO}_{2}$, water vapor, and energy from a prairie ecosystem during the seasonal transition from carbon sink to carbon source. Agricultural and Forest Meteorology, $89,1-14$

Harden, J., O’Neill, K. P., Trumbore, S. E., Veldhuis, H., \& Stocks, B. F. (1997). Accumulation and turnover of carbon in soils of the BOREAS NSA: 2. Soil contribution to annual net $\mathrm{C}$ flux in a maturing sprucemoss forest (OBS NSA). Journal of Geophysical Research, 102, $28805-28816$.

Harvard (2003). GPP data for HARV is at: ftp://ftp.as.harvard.edu/pub/ nigec/HU_Wofsy/hf_data/derived_data/>. GPP data for NOBS is at: $\mathrm{ftp}: / / \mathrm{ftp}$.as.harvard.edu/pub/nigec/Boreas_OBS/.

Heimann, M., Esser, G., Haxeltine, A., et al. (1998). Evaluation of terrestrial carbon cycle models through simulations of the seasonal cycle of atmospheric $\mathrm{CO}_{2}$ : First results of a model intercomparison study. Global Biogeochemical Cycles, 12, 1-24.

Heinsch, F. A., Reeves, M., \& Bowker, C. F. (2003). User's Guide, GPP and NPP (MOD 17A2/A3) Products, NASA MODIS Land Algorithm. http://www.forestry.umt.edu/ntsg/.

Houghton, R. A. (1999). The annual net flux of carbon to the atmosphere from change in land use 1850-1990. Tellus B, 51, 298-313.

Hunt Jr., E. R., Piper, S. C., Nemani, R., Keeling, C. D., Otto, R. D., \& Running, S. W. (1996). Global net carbon exchange and intra-annual atmospheric $\mathrm{CO}_{2}$ concentrations predicted by an ecosystem process model and three-dimensional atmospheric transport model. Global Biogeochemical Cycles, 10, 431-456.

IPCC (Intergovernmental Panel on Climate Change) (2001). In J. T. Houghton, Y. Ding, D. J. Griggs, M. Noguer, P. J. van der Linden, \& D. Xiaosu (Eds.), Climate Change 2001: The Scientific Basis Contribution of Working Group I to the Third Assessment Report of the IPCC (p. 944). UK: Cambridge University Press.

Jarvis, P. G., \& Leverenz, J. W. (1983). Productivity of temperate deciduous and evergreen forests. In O. L. Lange, P. S. Nobel, C. B. Osmond, \& H. Ziegler (Eds.), Ecosystem processes: Mineral cycling, productivity, and man's influence. Physiological Plant Ecology, New Series, vol. 12D (pp. 233-280). New York: Springer-Verlag.

Kimball, J. S., Keyser, A. R., Running, S. W., \& Saatchi, S. S. (2000). Regional assessment of boreal forest productivity using an ecological process model and remote sensing parameter maps. Tree Physiology, 20, $761-775$

Kimball, J. S., Running, S. W., \& Saatchi, S. S. (1999). Sensitivity of boreal forest regional water flux and net primary production simulations to sub-grid scale landcover complexity. Journal of Geophysical Research, 104, 27789-27801.

Kimball, J. S., Thornton, P. E., White, M. A., \& Running, S. W. (1997). Simulating forest productivity and surface-atmosphere carbon exchange in the BOREAS study region. Tree Physiology, 17, 589-599.

Lavigne, M. B., \& Ryan, M. G. (1997). Growth and maintenance respiration rates of aspen, black spruce and jack pine stems at northern and southern OREAS sites. Tree Physiology, 17, 543-551.

Law, B. E., Ryan, M. G., \& Anthoni, P. M. (1999). Seasonal and annual respiration of a Ponderosa Pine ecosystem. Global Change Biology, 5, $169-182$

Middleton, E. M., Sullivan, J. H., Bovard, B. D., Deluca, A. J., Chan, S. S., \& Cannon, T. A. (1997). Seasonal variability in foliar characteristics and physiology for boreal forest species at the five Saskatchewan tower sites during the 1994 Boreal Ecosystem-Atmosphere Study. Journal of Geophysical Research, 102, 28831-28844.

Myneni, R., Hoffman, Y., Knyazikhin, et al. (2002). Global products of vegetation leaf area and fraction absorbed PAR from one year of MODIS data. Remote Sensing of Environment, 76, 139-155. 
Nemani, R., White, M., Thornton, P., Nishida, K., Reddy, S., Jenkins, J., \& Running, S. (2002). Recent rends in hydrologic balance have enhanced the terrestrial carbon sink in the United States. Geophysical Research Letters, 29, 1061-1064.

ORNL (2003). Oak Ridge National Laboratory Mercury Data System. http://mercury.ornl.gov/ornldaac/. BigFoot Project. Compiled Meteorological Data.

Reich, P. B., Turner, D. P., \& Bolstad, P. (1999). An approach to spatially distributed modeling of net primary production (NPP) at the landscape scale and its application in validation of EOS NPP products. Remote Sensing of Environment, 70, 69-81.

Running, S. R., Baldocchi, D. D., Turner, D. P., Gower, S. T., Bakwin, P. S., \& Hibbard, K. A. (1999). A global terrestrial monitoring network integrating tower fluxes, flask sampling, ecosystem modeling and EOS satellite data. Remote Sensing of Environment, 70, 108-128.

Running, S. W. (1994). Testing FOREST-BGC ecosystem process simulations across a climatic gradient in Oregon. Ecological Applications, 4, $238-247$.

Running, S. W., \& Hunt, E. R. Jr. (1993). Generalization of a forest ecosystem process model for other biomes, BIOME-BGC, and an application for global scale models. In J. R. Ehleringer, C. Field (Eds.), Scaling physiological processes leaf to globe (pp. 141-158). San Diego, CA: Academic Press.

Running, S. W., Nemani, R. R., \& Hungerford, R. D. (1987). Extrapolation of synoptic meteorological data in mountainous terrain and its use for simulating forest evapotranspiration and photosynthesis. Canadian Journal of Forest Research, 17, 472-483.

Running, S. W., Thornton, P. E., Nemani, R., \& Glassy, J. M. (2000). Global terrestrial gross and net primary productivity from the Earth observing system. In O. E. Sala, R. B. Jackson, H. A. Mooney, \& R. W. Howarth (Eds.), Methods in ecosystem science (pp. 44-57). New York: Springer-Verlag.

Schimel, D. S. (1995). Terrestrial ecosystems and the carbon cycle. Global Change Biology, 1, 77-91.

Schmid, H. P. (2002). Footprint modeling for vegetation atmosphere exchange studies: A review and perspective. Agricultural and Forest Meteorology, 113, 159-183.

Schubert, S. D., Rood, R. B., \& Pfaendtner, J. (1993). An assimilated dataset for Earth science applications. Bulletin of the American Meteorological Society, 74, 2331-2342.
Sellers, P. J., Dickinson, R. E., Randall, D. A., Betts, A. K., Hall, F. G., Berry, J. A., Collatz, G. J., Denning, A. S., Mooney, H. A., Nobre, C. A., Sato, N., Field, C. B., \& Henderson-Sellers, A. (1997). Modeling the exchanges of energy, water, and carbon between continents and the atmosphere. Science, 275, 502-509.

Sellers, P. J., Hall, F. G., Kelly, R. D., Balck, A., Baldocchi, D., Berry, J., Ryan, M., Ranson, K. J., Crill, P. M., Lettenmaier, D. P., Margolis, H., Cihlar, J., Newcomer, J., Fitzjarrald, D., Jarvis, P. G., Gower, S. T., Halliwell, D., Williams, D., Goodison, B., Wickland, D. E., \& Guertin, F. E. (1997). BOREAS in 1997: Experiment overview, scientific results, and future directions. Journal of Geophysical Research, 102, 28731-28769.

Shewchuk, S. R. (1997). Surface mesonet for BOREAS. Journal of Geophysical Research, 102, 29077-29082.

Thornton, P. E., Law, B. E., Gholz, H. L., Clark, K. L., Falge, E., Ellsworth, D. S., Goldstein, A. H., Monson, R. K., Hollinger, D., Falk, M., Chen, J., \& Sparks, J. P. (2002). Modeling and measuring the effects of disturbance history and climate on carbon and water budgets in evergreen needleleaf forests. Agricultural and Forest Meteorology, 113, 185-222.

Trumbore, S. E., \& Harden, J. W. (1997). Accumulation and turnover of carbon in organic and mineral soils of the BOREAS northern study area. Journal of Geophysical Research, 102, 28817-28830.

Turner, D. P., Urbanski, S., Wofsy, S. C., Bremer, D., Gower, S. T., \& Gregory, M. (2003). A cross-biome comparison of light use efficiency for gross primary production. Global Change Biology, 9, 383-395.

White, M. A., Thornton, P. E., Running, S. W., \& Nemani, R. R. (2000). Parameterization and sensitivity analysis of the BIOME-BGC terrestrial ecosystem model: Net primary production controls. Earth Interactions, $4,1-85$.

Williams, M., Rastetter, E. B., Shaver, G. R., Hobbie, J. E., Carpino, E., \& Kwiatkowski, B. L. (2001). Primary production in an arctic watershed: An uncertainty analysis. Ecological Applications, 11, 1800-1816.

Wofsy, S. C., Goulden, J. W., Munger, S.-M.F., Bakwin, P. S., Daube, B. C., Bassow, S. L., \& Bazzaz, F. A. (1993). Net exchange of $\mathrm{CO}_{2}$ in a midlatitude forest. Science, 260, 1314-1317.

Woodward, F. I. (1987). Climate and plant distribution. Cambridge: Cambridge University Press. 